\title{
A NEW HISTORY OF BANKING PANICS IN THE UNITED STATES, 1825-1929: CONSTRUCTION AND IMPLICATIONS*
}

\author{
Andrew Jalil ${ }^{+}$ \\ University of California, Berkeley
}

November 1, 2009

\begin{abstract}
$\underline{\text { Abstract }}$
There are two major problems in identifying the output effects of financial panics of the pre-Great Depression era. First, it is not clear when panics occurred because prior panic series-lists of when panics occurred-combine panics with other developments in financial markets, fail to distinguish among different types of financial panics, and employ unreliable strategies to identify panics. Second, even if the timing of when panics occurred is consistent with panics having real output effects, establishing the direction of causality is tricky: are panics causing downturns or are downturns causing panics? This paper addresses these two problems (1) by developing a new panic series for the 1825-1929 period - one that rectifies many of the problems of earlier seriesand (2) by studying the output effects of major banking panics that the reports of contemporary observers suggest were the result of idiosyncratic disturbances, as opposed to declining output conditions. My paper derives four major empirical findings: (1) major banking panics have large and strongly negative effects on both output and prices, (2) panics were a substantial source of economic instability prior to the founding of the Federal Reserve, (3) on average, downturns with major banking panics were more severe than downturns without them and output recoveries were longer for downturns with major banking panics than output recoveries for downturns without them and (4) panics can have persistent level and trend effects. Moreover, using my new series, I find that much of the conventional wisdom on the causes, effects and frequency of panics of the pre-Great Depression era was based on unreliable evidence - and in particular, on biased and inconsistent panic series.
\end{abstract}

\footnotetext{
" I am indebted to J. Bradford DeLong, Barry Eichengreen, Christina Romer, and David Romer for their continuous guidance, advice and support. I thank participants at the Economic History Seminar at UC Berkeley and at the ALL-UC Group in Economic History Graduate Student Conference for helpful comments. The appendix to the paper can be downloaded at http://www.ocf.berkeley.edu/ ajalil

${ }^{+}$Department of Economics, University of California, Berkeley. E-mail: Andrew_Jalil@berkeley.edu
} 
What are the macroeconomic effects of banking panics? How long do the effects last? How might the downturn of 2008-2009 differ from other postwar recessions in the U.S.? Is this time really different?

The general absence of banking panics in the United States since the Great Depression means that there are few modern day equivalents to the unfolding crisis today. Indeed, there is a growing sense that this downturn may more closely resemble the downturns of the $19^{\text {th }}$ and early $20^{\text {th }}$ centuries that accompanied banking crises than the recessions of the postwar period. As Paul Krugman recently speculated, "this may be your great-great-grandfather's recession."

Surprisingly, the effects of financial panics of this era are not very well understood. Economists have recently arrived at contradictory conclusions. DeLong and Summers (1986), in studying the period 1890-1910, do not find a link between panics and real recessions, leading them to conclude that "the effects of financial panic upon the rest of the real economy are smaller than is usually realized." ${ }^{2}$ By contrast, over roughly the same period, Miron (1986) finds a clear correlation between panics and downturns. However, even with this finding, Miron cautions that his results do not prove that panics have real output effects since "panics might be the result of negative output shocks"3 rather than direct causes of downturns.

The inconclusive nature of this debate reflects the two major problems in identifying the effects of financial panics of the pre-Great Depression era. First, it is not clear when panics occurred because prior panic series - lists of when panics occurred — differ in their identification of panic episodes. Some series document panics occurring at a rate of more than one per year, whereas other series identify recurring periods of ten to twenty years without a panic. Methodological flaws in the development of these series account for these major discrepancies. Some series combine panics with other developments in financial markets. Others fail to distinguish among different types of panics. Many series employ inconsistent strategies to identify panics. Indeed, DeLong and Summers (1986) and Miron (1986) arrive at contradictory conclusions because they rely on different panic series to identify when panics occurred.

Second, even if the timing of when panics occurred is consistent with panics having real output effects, establishing the direction of causality is inherently difficult. Are panics causing downturns or are downturns causing panics? There are two schools of thought. According to one view, panics are shocks to the real economy that cause downturns, but according to the alternate view, panics are consequences of major recessions. Under this latter specification, even if a correlation between downturns and panics exists, it would be misleading to attribute output declines to panics since panics would be products of downturns rather than causes.

This paper seeks to identify the macroeconomic effects of a main class of financial panics of the pre-Great Depression era: banking panics. It accomplishes this by addressing these two major concerns. To address the first concern, this paper develops a new series on banking panics for the pre-Great Depression era. To address the second concern, this paper studies the output effects of major banking panics that the reports of contemporary observers suggest were the result of idiosyncratic disturbances, as

\footnotetext{
${ }^{1}$ Krugman, Paul. "Who'll Stop the Pain?” New York Times. Feb 19, 2009.

${ }^{2}$ Page 689.

${ }^{3}$ Page 137.
} 
opposed to declining output conditions. In the process, I find that much of the conventional wisdom on the causes, effects and frequency of panics of the pre-Great Depression era was based on unreliable evidence - and in particular, on biased and inconsistent panic series.

Section 1 begins by asking: when did the financial panics of the pre-Great Depression era occur? I show that - perhaps, somewhat surprisingly - answering this question is not a straightforward task. I document eight leading panic series - the (1) Bordo-Wheelock, (2) Thorp, (3) Reinhart-Rogoff, (4) Gorton, (5) Sprague, (6) Wicker, (7) Kemmerer, and (8) DeLong-Summers series-and demonstrate that each of these series would arrive at a different answer to this question. Indeed, these series differ dramatically in their identification of panic episodes. Some series-such as the Kemmerer and DeLongSummers series - document panics occurring at a rate of roughly one per year, whereas other seriessuch as the Thorp and Wicker series - identify recurring periods of ten to twenty years without a panic.

Why do these series differ so dramatically? By describing each of the panic series on a case-bycase basis, I show that methodological flaws in the development of earlier series are the likely source of these extreme variations. Many panic series do not explicitly define a panic, making it unclear exactly what kind of financial disturbance is being recorded. Other series employ inconsistent strategies to identify panics, raising the possibility that some panic episodes are omitted or that non-panic episodes are mistakenly classified as panics. A few series do not even provide any rationale for how they identify panics, rendering the reliability of those series questionable.

Due to the numerous contradictions across these series and the serious flaws that underpin the methodology behind many of these series, Section 2 develops a new panic series - one that rectifies many of the problems of earlier series. I begin by providing a definition of financial panic - one that distinguishes among different types of financial panics. Specifically, I define a financial panic as occurring when there is a widespread rush by private agents to liquidate assets, e.g., deposits in the banking sector (a banking panic), stocks in equity markets (a stock market panic), or currency in foreign exchange markets (a currency panic). In developing the new series, however, I restrict attention to a key type of financial panic: banking panics.

Due to data limitations, quantitative sources are not sufficient to identify banking panics. Comprehensive data on bank suspensions and bank failures are not available throughout much of the $19^{\text {th }}$ century. Therefore, I employ other sources to identify banking panics: financial and economic newspapers from the $19^{\text {th }}$ and early $20^{\text {th }}$ centuries. The press of that era devoted substantial resources to covering banking panics. Incidents of bank runs, suspensions and failures were regularly reported in contemporary newspapers, regardless of place of origin. Moreover, the newspapers that I employ contained detailed index pages. Of particular importance, the index pages provided information regarding banking panics. Reports of bank runs, suspensions, and failures, along with general entries for banking panics and financial crises were listed in the index pages.

Since the index pages of these newspapers provided comprehensive lists of economic, financial, and banking news, a careful examination of these pages locates banking panics reported in these newspapers. Thus, to identify banking panics, I read the index pages of contemporary newspapers-from 1825 to 1929 - for key terms that are likely to signal a banking panic. When I find such a term, I read the 
referenced article to see if any bank runs, suspensions or failures occurred. I identify banking panics in these articles by the occurrence of a cluster of bank runs and suspensions. To scale banking panics according to degree, I implement the following rule. A banking panic is classified as major if it meets two conditions: (1) it spans more than one geographic unit — defined as a state and its bordering states — and (2) it appears on the front page of the newspaper. All other banking panics are minor.

Section 3 presents the results of the new series and its implications. The new series on banking panics identifies seven major banking panics—1833, 1837, 1839, 1857, 1873, 1893, and 1907—as well as twenty minor banking panics between 1825 and 1929-thirteen of which are not listed in any of the earlier series.

Using my new series, I then assess the reliability of earlier series. By comparing my new series to earlier series and by reading contemporary news reports surrounding every panic episode on all eight series, I show that earlier series have some severe problems. Some series combined panics with other developments in financial markets. Others failed to distinguish among different types of financial panics. Indeed, several series lumped together different types of financial disturbances-banking panics, stock market disturbances, spikes in interest rates-under the common heading of panic. Moreover, a few series even went so far as to incorrectly identify foreign banking panics as domestic ones.

Next, I document the frequency of banking panics prior to the Great Depression. The orthodox view in the literature is that the frequency of financial panics was high before 1914 and that the frequency dramatically decreased between 1914 and 1929 — that is, during the first fifteen years of the existence of the Federal Reserve. Using my new series, however, I show that contrary to the conventional wisdom, there is no evidence of a decline in the frequency of panics during the first fifteen years of the existence of the Federal Reserve. Why do my findings differ from those of the literature? As it turns out, prior studies used the Kemmerer series - a series that the analysis in this paper shows to be severely flawed-to document the pre-1914 frequency of panics, leading to spurious conclusions regarding the historical frequency of panics.

Equipped with the new panic series, section 4 presents the empirical test I conduct to identify the real output effects of major banking panics. I begin by documenting a correlation between major banking panics and downturns. However, the primary problem in identifying the output effects of banking panics is the possibility that panics might be consequences - rather than causes - of downturns. The existence of a correlation between panics and downturns, by itself, does not prove that panics have real output effects. If panics are products of recessions, then deteriorating economic conditions might be causing panics, rather than vice versa. Under this specification, it would be misleading to attribute output declines to panics since panics would be products of downturns rather than causes.

This identification problem is made even more complicated for the panics of the pre-Great Depression era due to data limitations. Many of the output series dating back to the 1800 s are available at only a yearly frequency, making it difficult to identify whether panics preceded downturns or occurred in the midst of downturns. If time series data on output were available at a greater frequency, it might be possible to identify the timing of panics in relation to the timing of output declines. If, for example, panics precede output declines, then it might be possible to conclude that panics caused the output 
declines, rather than vice versa. But in the absence of such data, this is not possible. This complicates efforts to disentangle the effects of a panic from those on an ongoing downturn and to establish a clear direction of causality.

Consequently, I develop a new test of the output effects of banking panics - one that circumvents many of these concerns by drawing on additional evidence. Financial and economic newspapers from the 1825-1929 period contain detailed commentaries by contemporary observers that clarify many of these issues. In particular, I read the newspaper records surrounding every major banking panic between 1825 and 1929 to identify those banking panics that (1) did not break out in the midst of a major downturn and that (2) were caused by events unrelated to movements in output-for example, political decisions, international contagion, or the failure of a mismanaged bank. I then use these episodes to empirically identify the output effects of banking panics.

Section 4.1 describes in greater detail how I use the reports of contemporary observers to separate banking panics that may have been caused by downturns from those that were the result of other disturbances. I place particular emphasis on how the newspaper records can help identify the causes of panics and how they can help reveal whether a panic broke out in the midst of a major downturn. Descriptions of events leading up to panics and reports by contemporary observers help to pinpoint the forces that precipitated depositor anxiety and that led to a panic. Descriptions of the state of the economy in the period immediately preceding the panic clarify whether there were indications of a major recession on the eve of the outbreak of panic. Both pieces of information are helpful in determining whether a panic was caused by a downturn or by some other disturbance. Did depositors panic because there were growing signs of a depression or did they panic in response to some other disturbance?

Since I rely on qualitative evidence to separate banking panics that may have been caused by downturns from those that were caused by other events, there are varying degrees of certainty across episodes. In some cases, the causes of a panic are clear and obvious, whereas in other cases, the causes are more ambiguous. To reflect these varying degrees of certainty and to make my methodology as transparent as possible, I classify panics on a scale. Section 4.1 presents the algorithm I use to classify panics on this scale, whereas section 4.2 describes on a case-by-case basis the classification of panics on this scale.

Section 4.3 presents the empirical findings. Equipped with a listing of panics that did not break out in the midst of a major downturn and that were caused by events unrelated to movements in output, I examine the macroeconomic effects of banking panics. I find that major banking panics have large and strongly significant effects on both output and prices. My results indicate that major banking panics cause declines of 9 to 13 percentage points in output growth in the year following a panic and declines of 11 to $13 \%$ in the price level within one year. The results are robust to a variety of specifications.

Armed with a reliable listing of when panics occurred, Section 4.4 investigates whether banking panics were a significant a source of output volatility prior to the founding of the Federal Reserve. I find that nearly half of all business cycle downturns between 1825 and 1914 contained major banking panics. If wartime cycles are excluded, then $58 \%$ of business cycle downturns contained major banking panics. According to the estimates I derive in section 4.3, banking panics have large output effects. Thus, even if 
banking panics did not initiate all of these downturns, they amplified them. These findings suggest that banking panics were a substantial source of economic instability throughout much of US history and that major banking panics either caused or amplified nearly half of all business cycle downturns between 1825 and 1914. These results contradict those of DeLong and Summers (1986), who argue - using their panic series - that financial panics were not a principal cause of economic instability before the Second World War.

Then, equipped with an accurate listing of when panics occurred, section 4.5 examines how downturns with major banking panics differed from downturns without major banking panics. I find that in the post-Civil War era, downturns with major banking panics were slightly longer and substantially more severe than downturns without major banking panics on average, and that output recoveries for downturns with major banking panics were two-to-three times the length of output recoveries for downturns without them.

Section 4.6 concludes by analyzing the dynamics of output following banking panics. I find that major banking panics can have persistent level and trend effects. Following three of the four major banking panics of the post-Jacksonian period, output did not revert back to its pre-panic trend. Moreover, following two of these panics, trend output growth declined substantially. These results are consistent with the growing consensus in the literature that banking crises can have lasting effects on output. The results of this section have implications for what might happen to output following the banking crisis of 2007-2009. Furthermore, these results underscore the stakes of the current crisis.

\section{Part I. Prior Panic Series}

\subsection{When did Financial Panics Occur?}

When did financial panics occur? Surprisingly, answering this question is not a simple task. Table 1 presents eight different panic series: the (1) Bordo-Wheelock, (2) Thorp, (3) Reinhart-Rogoff (two versions), (4) Gorton, (5) Sprague, (6) Wicker, (7) Kemmerer, and (8) DeLong-Summers series. ${ }^{4}$ Each panic series comes from a different study and covers a different period, noted in the first and third rows of Table 1, respectively. A perusal of table 1 quickly reveals that there is substantial disagreement across these series regarding the timing, incidence, and frequency of panics throughout U.S. history. Each empty cell represents a panic noted in at least one series that is not contained in the series corresponding to that column.

Consider first the period between 1825 and the end of the Civil War. The three series that span the 1825-1864 period, the Thorp, Bordo-Wheelock, and Reinhart-Rogoff series, identify 1825 and 1857 as panics. ${ }^{5}$ However, there is significant disagreement regarding other episodes. The Bordo-Wheelock and

\footnotetext{
${ }^{4}$ The series come from the following studies: (1) Bordo and Wheelock (1988), (2) Thorp (1926), (3) Reinhart and Rogoff (2008c), (4) Gorton (1988), (5) Sprague (1910), (6) Wicker (2000), (7) Kemmerer (1910), DeLong and Summers (1986). Reinhart and Rogoff (2008c) provide two versions of their panic series. They list one version in Table A3 and another version in Table A5. The two versions occasionally contradict one another. As a consequence, I provide both versions in Table 1.

${ }^{5}$ The Reinhart-Rogoff series uses the term crisis rather than panic.
} 
Thorp series identify 1833 as a panic, while both versions of the Reinhart-Rogoff series omit 1833 . The Bordo-Wheelock and Thorp series identify 1837 and 1839 as two distinct panics, whereas one version of the Reinhart-Rogoff series combines the financial disturbances of the late 1830s into one panic, beginning in 1836, while the other version identifies a sole panic from March 1837 to 1838. The Thorp series identifies 1847 as a panic, whereas the other series do not identify 1847 as a panic. One version of the Reinhart-Rogoff series identifies December 1861 and April 1864 as banking crises, whereas the other series do not contain these episodes.

From 1864 to 1914, the series concur in classifying 1873, 1893 and 1907 as panics, with the exception of one version of the Reinhart-Rogoff series, which omits the 1893 panic, and the Sprague series, which labels these three episodes crises rather than panics. However, there is significant disagreement on the disturbances of 1884 and 1890. The Reinhart-Rogoff, Gorton, and Kemmerer series identify 1884 and 1890 as panics. ${ }^{6}$ The DeLong-Summers series, which begins in 1890, also identifies 1890 as a panic. However, the Wicker series classifies 1884 and 1890 as incipient panics, rather than full-scale panics. The Bordo-Wheelock series also makes a distinction for these two episodes, classifying them as 'financial distress' rather than panics. The Sprague series distinguishes 1884 and 1890 from the crises of 1873,1893 and 1907 by classifying 1884 as a panic and 1890 as financial stringency. The Thorp series omits 1884 and 1890. Moreover, there is little consensus for the other panics of this period. The Bordo-Wheelock series classifies 1878 as "financial distress," whereas the other series omit this episode. The Gorton series classifies October 1896 as a panic, the DeLong-Summers series identifies two panics in 1896, one in the first quarter and a second in the third quarter of the year, and the Kemmerer series identifies two panics in 1896, one from June to July and another in December. By contrast, the BordoWheelock, Thorp, Reinhart-Rogoff, Sprague and Wicker series do not classify 1896 as a panic. The Reinhart-Rogoff and Gorton series classify 1914 as a panic, while the Bordo-Wheelock, Thorp, and Wicker series omit 1914. Furthermore, the Kemmerer series includes three additional major panics - Dec 1899, May 1901, and Mar-Aug 1903 - and twenty-one minor panics. None of the other series contain any of Kemmerer's minor panics and only one series-the DeLong-Summers series-contains Kemmerer's additional major panics. Moreover, the DeLong-Summers series contains three additional panic quarters - none of which are noted in any of the other series.

The series that extend to the 1930 s contain the panics of the Great Depression. The BordoWheelock series also identifies episodes of financial distress in the 1920s and 1980s. Both versions of the Reinhart-Rogoff series identify 1984 as a banking crisis and one version of the Reinhart-Rogoff series identifies 2007 as a banking crises.

\subsection{Studies on the Output Effects and Causes of Panics Depend on the Panic Series}

An understanding of when panics occurred is critical to studies on the real output effects and causes of panics. Studies on the real output effects of panics depend on the panic series to identify the timing of panics in relation to changes in output. Studies on the causes of panics depend on the panic series to

${ }^{6}$ One version of the Reinhart-Rogoff series omits the 1890 episode. Both versions, however, contain the 1884 episode. 
identify the timing of panics in relation to forces that may have increased the susceptibility of the financial system to a panic.

First, consider studies that examine the real output effects of panics of the pre-Federal Reserve era. DeLong and Summers (1986) do not find a link between panics and downturns. They compare the behavior of output surrounding their twelve panic periods with the behavior of output in non-panic periods from 1890-1910. They conclude that no more than a small portion of the variance in output from 1890-1910 can be attributed to these panics, and that as a consequence, panics did not have significant real output effects. DeLong and Summers write, this suggests that financial and monetary shocks are less important sources of depression than we had suspected...Is there any way to rationalize the apparent lack of strong links between financial uproar and real recession? We believe that the conclusions of the exercise above are reasonable, because the effects of financial panic upon the rest of the real economy are smaller than is usually realized. ${ }^{7}$

On this basis, DeLong and Summers conclude that the real output effects of panics are small.

However, their results critically depend on their panic series to identify the timing of panics in relation to changes in output. If the DeLong-Summers series is accurate in identifying twelve panics from 1890 to 1910 that had little impact on output fluctuations, then their conclusion that there is not a strong link between financial panics and real downturns might be well supported. However, if their series mischaracterizes non-panic episodes as panics, then they would be attributing the behavior of output in non-panic episodes to the behavior of output in panic episodes, rendering their conclusions regarding the output effects of panics spurious. That the DeLong-Summers series includes panics not noted in other series raises this concern.

By contrast, Miron (1986) comes to a different conclusion using the Kemmerer series of major panics for the 1890-1908 period-roughly the same period studied by DeLong and Summers. Miron notes that the average level of GNP growth almost doubles when panic years are excluded - a finding much more consistent with panics having real effects. Romer (1999), also using the Kemmerer series, reaches a similar conclusion, noting a strong correlation between recessions and panics. However, the Kemmerer series also includes many episodes not noted in other series, rendering its reliability questionable.

Studies on the causes of panics also depend on the panic series. In particular, one of the leading studies on the causes of panics of the pre-Fed era-Miron (1986) - hinges on its choice of panic series. Miron argues that seasonal monetary forces generated recurring panics prior to the founding of the Federal Reserve. Increased demand from the agricultural sector for currency and credit in the spring planting season and fall-crop moving season caused seasonal "stringencies" in the money market, forcing interest rates up and bank reserve-to-deposit ratios down. These forces weakened the nation's banking system and caused a contraction in the money supply in the fall and spring, precisely when the demand for money increased. This fundamental flaw in the operation of the nation's monetary system - known as 'the perverse elasticity' of the money supply_produced seasonal, recurring panics, according to Miron. He uses the Kemmerer series to conclude that panics of the pre-Fed era had a tendency to recur during

\footnotetext{
${ }^{7}$ Page 689 .
} 
those seasons characterized by stringent monetary conditions - that is, the fall and spring. Miron's analysis of the pre-Fed era covers 1890 to 1908, and he notes that two-thirds of Kemmerer's 21 panics of this period occurred during the fall or spring, with seven occurring in the spring months of March, April or May and seven occurring in the fall months of September, October or November.

Miron then claims that there were no panics between 1914 and 1929, the first fifteen years of the existence of the Federal Reserve. This stark contrast-twenty-one panics between 1890 and 1908, compared to zero panics between 1914 and 1929-leads him to the conclusion that the Federal Reserve caused a dramatic reduction in the frequency of panics after 1914. He cites the establishment of an elastic currency — one that could expand and contract when needed — as the policy action that mitigated seasonal stringencies in the money market, thereby reducing the frequency of panics. However, since Miron uses the Kemmerer series to document the incidence of panics before 1914, Miron's conclusionsin terms of both the seasonality of panics prior to 1914 and the reduction in the frequency of panics between 1914 and 1929—-hinge on the Kemmerer series.

\subsection{Methodology Behind the Eight Panic Series}

Why do these panic series differ so dramatically? This section describes the methodologies behind each of the eight panic series on a case-by-case basis.

\section{$\underline{\text { Kemmerer }}$}

Kemmerer (1910) identified financial panics by reading the Commercial and Financial Chronicle, the leading economic newspaper of the late $19^{\text {th }}$ and early $20^{\text {th }}$ centuries, from 1873 to 1908 . He found eight major and twenty-one minor panics. However, he provided almost no explanation for his methodology. He did not provide a clearly defined criterion for selecting major and minor panic episodes, nor did he provide a definition of panic. For the major panics, he chose periods that were "financial disturbances" ${ }^{8}$ without explaining what that term encompassed, and for minor panics, he did not provide any rationale for his selection process.

Moreover, when describing his panics, Kemmerer wrote, "the word panic has been used here to cover several financial disturbances for which many would not use so strong a word, i.e., the disturbances of $1884,1890,1899$, and 1901 " (p. 223). In this quote, he openly acknowledged that his decision to classify several of these episodes as panics was questionable. Furthermore, in a footnote, Kemmerer provided a cautionary message regarding the methodology he used to identify his minor panics, noting that such a list was created after "a rather hasty perusal of the [Commercial and Financial] Chronicle" (p.223) and that "this list is probably not complete, and there may be room for doubt as to the inclusion of some of the dates mentioned" (p. 223).

\footnotetext{
${ }^{8}$ Page 223.
} 
Thorp

Thorp (1924), in his classic work Business Annals, one of the early pioneering studies on the history of business cycles, identified twelve panics in his yearly headings of major economic events from 1790 to 1925 . He assembled his list by reading newspapers; however, he failed to explain his rationale in identifying those twelve episodes as panics. He provided no explanation of his methodology, nor did he provide a definition of panic.

\section{DeLong and Summers}

DeLong and Summers (1986) identified twelve panics from 1890 to 1910 , with a panic being defined as a period when the average commercial paper rate over one quarter increases by one percentage point from quarter-to-quarter or when banks stop paying deposits at par. Eight of these panics satisfy the first criterion, a quarter-to-quarter increase in the average quarterly commercial paper rate of more than one percentage point. They are 1890:4, 1893:2, 1893:3, 1896:1, 1896:3, 1898:2, 1899:4, and 1905:4. The remaining four episodes were, presumably, classified as panics on the basis of the second criterion. DeLong and Summers likely chose to classify panics accordingly because spikes in the commercial paper rate suggest tight monetary conditions, while the cessation of paying out deposits at par indicates a degree of caution on the part of banking authorities. However, such conditions do not necessarily translate into bank failures, bank runs or stock market crashes, making it unclear whether the episodes identified by DeLong and Summers were in fact panics.

To illustrate this point, consider extending the DeLong-Summers series beyond the 1890-1910 period to the 1875-1889 and 1911-1983 periods on the basis of the first criterion, which identifies a panic by a quarter-to-quarter increase of one point or more in the average commercial paper rate. This methodology finds the following additional panics: 1875:4, 1876:4, 1877:3, 1878:4, 1881:1, 1886:4, 1887:3, 1889:4, 1914:3, 1931:4, 1958:4, 1973:2, 1974:2, 1974:3, 1978:4, 1979:4, 1980:1, and 1980:4. This list omits several of the banking panics of the Great Depression - the banking panic in the fall of 1930, the banking panic in the spring of 1931, and the banking panic of 1933 - as well as the Stock Market Crash of 1929. Given that a quarter-to-quarter increase of one point or more in the average commercial paper rate fails to identify several of the major financial panics of the Great Depression, it is unlikely that this criterion is an effective way to identify panics. Moreover, this criterion also would not have identified the panic of 1907 . $^{9}$

\section{Sprague}

Sprague (1910) described five episodes of financial unrest during the National Banking era- three crises $(1873,1893,1907)$, one panic (1884), and one episode of monetary stringency (1890). His classification suggests that he regarded the disturbances of 1884 and 1890 as of a different nature from the disturbances of 1873, 1893 and 1907, and yet he did not explicitly describe why he labeled each episode accordingly, nor did he provide a precise definition of crisis, panic or monetary stringency.

\footnotetext{
${ }^{9}$ The commercial paper rate data come from Table 2 - Appendix B of Gordon (1986).
} 
In addition, Sprague did not provide an explanation of how he assembled his listing of panics. Did he adopt a systematic methodology to study newspapers or to analyze macroeconomic variables to identify panic episodes or was he more selective in his approach, choosing panics that he already knew existed and thereby potentially missing other important episodes?

\section{Gorton}

Gorton (1988) defined a banking panic as follows:

A bank panic occurs when depositors demand such a large-scale transformation of deposits into currency that, at the contracted for exchange rate (of a currency dollar for a dollar deposit), the banking system can only respond by suspending convertibility of deposits into currency, issuing clearinghouse loan certificates, or both... To be clear, a bank run refers to a situation in which depositors at a single bank seek to exchange their deposits for currency. A banking panic refers to the situation in which depositors at all banks want to withdraw currency. ${ }^{10}$

Using this definition, Gorton found seven disturbances from 1863 to 1914 that fit this definition: suspension of convertibility occurred in five episodes $(1873,1890,1893,1907$ and 1914) and the issuance of loan certificates occurred in six episodes (1873, 1884, 1890, 1893, 1907 and 1914). To this list, Gorton added 1896, writing that the issuance of Clearing House loan certificates was authorized even though none were actually issued.

However, a concern with the Sprague series recurs with the Gorton series. It is not entirely clear how Gorton identified his seven panic observations, raising the possibility that some important episodes might be omitted. ${ }^{11}$

\section{$\underline{\text { Reinhart and Rogoff }}$}

Reinhart and Rogoff (2008c) identified banking crises if one of two events occurred:

"(1) bank runs that lead to the closure, merging, or takeover by the public sector of one or more financial institutions

(2) if there are no runs, the closure, merging takeover, or large-scale government assistance of an important financial institution (or groups of institutions), that marks the start of a string of similar outcomes for other financial institutions" (p. 58)

To find banking crises from 1800 to 2008 , they "rely on existing studies of banking crises and on the financial press." 12 A potential weakness of their methodology involves their dependence on previous studies. $^{13}$ Any errors embedded in earlier studies would simply be transplanted over to their series. Moreover, while Reinhart and Rogoff mention that they used the financial press, it is unclear how they used it.

Even putting these issues aside, Reinhart and Rogoff provide two - at times, contradictoryversions of their series on banking crises. One version of their series is presented in Table A3 of their

\footnotetext{
${ }^{10}$ Page 223.

${ }^{11}$ For example, according to the December 1899 edition of the Commercial and Financial Chronicle, the Boston Clearing House issued loan certificates to the Globe National Bank in the midst of a minor disturbance. Gorton failed to classify that episode as a panic even though clearinghouse loan certificates were issued, raising the possibility that Gorton may have missed other episodes.

12 Page 57.

${ }^{13}$ Specifically, Conant (1915), Bordo and Eichengreen (1999), Bordo et al. (2001), Bernanke and James (1991).
} 
paper, whereas the other version is presented in Table A5. While the two versions agree on many crises, they disagree on several episodes.

\section{Bordo and Wheelock}

Bordo and Wheelock (1988) identified banking panics on the basis of previous studies by Schwartz (1988), Thorp (1926), Sprague (1910), and Friedman and Schwartz (1963). The main concern with the Reinhart-Rogoff series reappears with the Bordo-Wheelock series. Any errors embedded in earlier studies would simply be transplanted over to their series.

\section{$\underline{\text { Wicker }}$}

Between the end of the Civil War and the founding of the Federal Reserve, Wicker (2000) identifies three major banking panics - 1873, 1893, and 1907—and two incipient banking panics—1884 and 1890. He classifies 1884 and 1890 as incipient rather than full banking panics because, he argues, policy intervention - on the part of the New York Clearing House - acted to "forestall a banking panic.", However, the counterfactual - whether a panic would have occurred in the absence of policy intervention and hence, whether these disturbances really were incipient panics-is unobservable. Moreover, it also seems likely that Wicker intended his work as a set of individual case studies on the five most cited banking disturbances of this era, rather than as a complete series that lists when every banking panic occurred between 1865 and 1914.

\subsection{Necessity of a New Panic Series}

The numerous contradictions across these series and the potential flaws that underpin the methodology behind many of these series necessitate the development of a new panic series and a reexamination of many of the leading arguments on the effects and causes of financial panics that have been formulated using these series. Do panics have significant real output effects? Are panics associated with declining real economic activity or are they associated with relatively stable economic performance? Can panics account for a significant fraction of the volatility in output in the 1800s and early 1900s? Were panics of the pre-Federal Reserve era caused by seasonal agricultural shocks? Or did other forces cause them? Is the claim that the frequency of financial panics decreased following the founding of the Fed accurate? Or is it a spurious conclusion drawn from a biased panic series?

The development of a new, consistent series on panics will be more than an important exercise in taxonomy; it will serve as a crucial tool for analyzing the causes, effects, and frequency of panics throughout US history.

\section{Part II. Development of a New Series on Banking Panics}

This section develops a new series on banking panics. I begin by providing a definition of financial panic — one that distinguishes among different types of financial panics. I then describe the methodology

\footnotetext{
${ }^{14}$ Page xv.
} 
I use to compile the new series on banking panics. In particular, I develop a clearly defined rule to identify banking panics from 1825 to 1929 .

\subsection{Definition of Financial Panic}

A financial panic occurs when there is a widespread rush by private agents to liquidate assets, e.g., deposits in the banking sector (a banking panic), stocks in equity markets (a stock market panic), or currency in foreign exchange markets (a currency panic). The principal characteristic of any financial panic - the rush to liquidate assets - is driven out of fear that a particular type of asset will suddenly decline in value or be rendered illiquid.

My definition of financial panic distinguishes among different types of financial panics: banking panics, stock market panics, and currency panics. A banking panic occurs when there is an increase in the demand for currency relative to deposits that sparks bank runs and bank suspensions. A stock market panic occurs when there is a rush to liquidate stocks in equity markets, resulting in sharp declines in stock prices. A currency panic occurs when agents sell currency in foreign exchange markets out of fears of devaluation. In each of these types of financial panics, there is a rush by private agents to dispose of a particular kind of asset—bank deposits in the case of banking panics, stocks in the case of stock market panics, and currency in the case of currency panics.

In developing a new panic series, however, I restrict my attention to one type of financial panic: banking panics. I leave the development of a series on stock market or currency panics for later work.

\subsection{Identifying Banking Panics}

Quantitative sources are not sufficient to identify banking panics. Consistent data series on bank suspensions and failures are not readily available throughout much of the $19^{\text {th }}$ century. Beginning in 1865, a consistent series on national bank failures - provided by the Comptroller of the Currency - exists. However, the data on national bank failures are only available at a yearly frequency, making it difficult to determine whether bank failures were clustered together — as would be the case in a banking panic — or whether they were spread out over the course of a year. Furthermore, even if one were to overlook this shortcoming, the Comptroller's series on national bank failures omits state banks, private banks, and trust companies, making the series unrepresentative of the overall banking system. ${ }^{15}$ Lastly, data on bank failures or suspensions, by itself, does not reveal whether there was a panic by depositors since a cluster of bank suspensions or failures can occur without runs by depositors.

To overcome these limitations, I employ other sources to identify banking panics: financial and economic newspapers from the $19^{\text {th }}$ and early $20^{\text {th }}$ centuries. The press of that era devoted substantial resources to covering banking panics. Incidents of bank runs, suspensions and failures were regularly reported in contemporary newspapers, regardless of place of origin. Indeed, disturbances occurring in the

\footnotetext{
${ }^{15}$ Grossman (1993) reports that the Comptroller of the Currency provided a series on both national and state bank failures. Due to regular inspections and uniform reporting rules, the Comptroller's series on national bank failures is reliable. However, the same level of consistency in reporting did not apply to the Comptroller's series on state bank failures, rendering the reliability of that series questionable.
} 
less populated regions of the interior as well as those occurring in more populated urban centers received significant attention by the press. Consequently, contemporary newspapers contain a detailed, comprehensive record of when and where banking panics occurred.

Therefore, to identify banking panics, I utilize contemporary newspapers. In particular, I use three newspapers: the Niles Weekly Register, The Merchants' Magazine and Commercial Review, and The Commercial and Financial Chronicle. These three newspapers were among the leading economic and financial newspapers of their day. Most importantly, they provided comprehensive coverage of developments in the banking sector, with special attention placed to reporting incidents of bank runs, suspensions and failures. I use the Niles Weekly Register for the period 1825 to 1849, The Merchants' Magazine and Commercial Review for the period 1842 to 1869, and The Commercial and Financial Chronicle for the period 1865 to $1929 .{ }^{16}$

These newspapers were printed on a regular basis and were bound in volumes for preservation. The Niles Weekly Register and The Commercial and Financial Chronicle were published on a weekly basis, and The Merchants' Magazine and Commercial Review on a monthly basis. Editions of the Niles Weekly Register and The Merchants' Magazine and Commercial Review were bound in six-month volumes. Editions of The Commercial and Financial Chronicle were bound in six-month volumes from 1865 to 1916 and three-month volumes from 1917 to 1929.

The bound volumes of all three newspapers contained index pages. The index pages provided detailed lists of specific information found in each volume, arranged alphabetically. Each item listed in the index was matched to its respective page number, permitting readers to quickly identify its precise location in the volume. Of particular importance, the index pages provided information regarding banking panics. Reports of bank runs, suspensions, and failures, along with general entries for banking panics and financial crises were listed in the index pages. ${ }^{17}$

Since the index pages of these newspapers provided comprehensive lists of economic, financial, and banking news, a careful scanning of these pages locates banking panics reported in the Niles Weekly Register, the Merchants' Magazine and Commercial Review, and the Commercial and Financial Chronicle. Therefore, to identify banking panics, I read the index pages of these newspapers-from 1825 to 1929-for key terms that are likely to signal a banking panic. In particular, I search for any of the following terms: bank failure, bank suspension, bank run, bank closure, bank crisis, bank panic, bank disturbance, crash, crisis, financial crisis, financial disturbance, financial revulsion, panic, revulsion, run,

\footnotetext{
${ }^{16}$ The Merchants' Magazine and Commercial Review was first published in July 1839, but it did not contain the "Monthly Commercial Chronicle" section-the key section that covered contemporaneous economic news-until April 1842. During its early years, from July 1839 until March 1842, The Merchants' Magazine and Commercial Review devoted little coverage to current news.

${ }^{17}$ The index pages are consistent over the 1825 to 1929 period in that they comprehensively report incidents of bank runs, suspensions and failures. However, the structure of these index pages changed somewhat over time and across different newspapers. For example, The Merchants' Magazine and Commercial Review split its listing of articles into an Index page and a Contents page. Even though it is not officially labeled an index page, the Contents page serves in that capacity and consequently, I treat it as such. Also, the Commercial and Financial Chronicle split its index into several different index pages that varied across years.
} 
suspension, suspension of payments and suspension of specie payments. ${ }^{18}$ When I find one of these terms in an index page, I read the referenced article to see if any bank runs, suspensions or failures occurred. ${ }^{19}$

Since a banking panic occurs when there is a loss of depositor confidence that sparks runs on financial institutions and bank suspensions, I identify banking panics in these newspaper articles by the occurrence of a cluster of bank suspensions and runs. The presence of both runs and suspensions is a necessary criterion. A wave of bank suspensions without runs would not be classified as a banking panic because a key feature of a banking panic is a rush by depositors to convert deposits into currency. ${ }^{20}$ Similarly, runs on institutions that did not produce bank suspensions would not be classified as a banking panic.

Moreover, to separate isolated bank runs and suspensions from banking panics, which are more generalized disturbances that extend beyond the confines of individual bank-specific problems, I identify banking panics by a cluster of bank suspensions and runs. To avoid any ambiguity, I define a cluster as three or more banks. ${ }^{21}$ Lastly, to partition banking panics, I implement the following rule: a panic ends if there are no reports of any bank runs or suspensions for one full calendar month.

\subsection{Scaling Banking Panics}

To reflect varying degrees, I classify each banking panic as major or minor. A banking panic is classified as major if it meets two conditions: (1) it spans more than one geographic unit and (2) it appears on the front page of the newspaper. All other banking panics are minor. I define a geographic unit as a state and its bordering states. For example, bank runs and suspensions that occur in Ohio, Indiana and Illinois would be contained in one geographic unit, whereas bank runs and suspensions that occur in Ohio, Indiana, Illinois and Pennsylvania would not be contained in one geographic unit.

Scaling banking panics according to geographic extent serves two useful purposes. First, it separates more localized disturbances from more widespread disturbances. A banking panic that occurs in one part of the country, but does not spread to other regions would seem to be a more minor disturbance than a banking panic that involves a generalized loss of depositor confidence throughout many parts of the nation. Separating more localized disturbances from more widespread disturbances

\footnotetext{
${ }^{18}$ In compiling this list, I chose words that describe key features of banking panics-failure, suspension, run, crisis, panic, disturbance, crash. One of the terms-revulsion-was widely used in the $19^{\text {th }}$ century to denote financial panics even though it has fallen out of use today. Moreover, in scanning indexes for key terms, I take into consideration the possibility of a rearrangement of words. For example, suspension of payments could be listed as "payments, suspension of" and suspension of specie payments could be listed as "specie payments, suspension of."

${ }^{19}$ To facilitate the process, the index pages of all three newspapers are alphabetical. The contents page of the Hunt's Merchants' Magazine and Commercial Review is chronological, and as a consequence, I read every entry. One of the index pages contained in the Commercial and Financial Chronicle - the Current Events and Discussion Page-is alphabetical, but occasionally, it listed banking panics under region; therefore, I read every entry.

${ }^{20}$ The newspapers do not need to use the word "run" if the action is described in other terms. For example, "heavy withdrawals" or "a depletion of reserves by depositors"-alternative ways of describing a sharp increased demand for currency by depositors-would be considered runs.

${ }^{21}$ For a bank run or suspension to be treated as part of a cluster, the report containing the bank run or suspension must contain a reference to other bank runs or suspensions or there must be reports of a general panic. This avoids classifying scattered, unconnected bank runs and suspensions as a cluster.
} 
clarifies the degree of the panic. Second, geographic extent is measurable and hence, not susceptible to personal discretion. Given the lack of bank-specific data throughout the 1800s, geographic extent provides a measurable criterion for classifying panics according to degree.

However, scaling banking panics according to geographic extent is not a flawless measure of degree. It is entirely plausible that a banking panic could have spanned more than one geographic unit, but have remained a minor disturbance. Consider for example, a banking panic that spanned more than one geographic unit, but that remained confined to a few states with small banking sectors. While such a disturbance might have seriously affected the local economy of those states, a panic of that nature might have been a minor disturbance from the perspective of the overall banking system. To overcome this potential problem, I require that all major banking panics be reported on the front page of the newspaper - the Niles Weekly Register for 1825-1849, the Merchants' Magazine and Commercial Review for 1842-1879, and the Commercial and Financial Chronicle for 1865-1929 - to ensure that only the most serious episodes of banking distress are classified as major banking panics. ${ }^{22}$

\section{Part III. The New Panic Series and Its Implications}

This section presents the results of the new series on banking panics and its implications. I begin by documenting the incidence of banking panics between 1825 and 1929. I then assess the reliability of earlier series by comparing them to my new series and by reading contemporary news reports surrounding every panic episode on all eight series. Next, equipped with my new series, I document the historical frequency of banking panics. Lastly, I investigate whether banking panics displayed a seasonal tendency prior to 1914 and I examine whether banking panics were correlated with downturns.

\subsection{Results}

Table 2 presents the new banking panic series. The new series identifies seven major banking panics and twenty minor banking panics between 1825 and 1929. The seven major banking panics are the following: (1) Nov 1833 - Apr 1834, (2) Mar - May 1837, (3) Oct 1839, (4) Aug - Oct 1857, (5) Sep 1873, (6) May - Aug 1893, and (7) Oct - Nov 1907.

The twenty minor banking panics are the following, with location in brackets: (1) Jan-Apr 1841 [PA, DE, MD, NC, VA], (2) Mar 1842 [PA], (3) May - Jun 1842 [New Orleans], (4) Oct 1851 [NY, NJ, MD], (5) Sep 1854 - Feb 1855 [OH, IN, MI, WI, IA, MO, NY, CA], (6) Nov 1860 [suspension of specie payments by banks in the South, citywide suspensions in Philadelphia, and Baltimore], (7) Dec 1861 [generalized suspension of specie payments], (8) May 1884 [NYC, PA, NJ], (9) Nov 1890 [NYC], (10) Dec 1896 [MN, IL], (11) Dec 1899 [Boston and New York City], (12) Jun - Jul 1901 [Buffalo and NYC], (13) Oct 1903 [PA, MD], (14) Dec 1905 [Chicago], (15) Jan 1908 [NYC], (16) Aug - Sep 1920 [Boston], (17) Nov 1920-Feb 1921 [ND], (18) Jul 1926 [FL, GA], (19) Mar

\footnotetext{
${ }^{22}$ By front page, I refer to the first page of the newspaper, with the exception of Index or Contents pages. If the first page of the newspaper is an Index or Contents page, then I treat the first page following the Index or Contents page as the front page.
} 
1927 [FL], and (20) Jul - Aug 1929 [FL]. Descriptions of each of these banking panics - with citations to the contemporary news articles reporting them-are contained in the appendix to this paper. ${ }^{23}$

The new series contains many banking panics not noted in earlier series. While most of the major banking panic episodes from the new series are noted in earlier series, thirteen of the twenty minor banking panics are not listed in any of the earlier series. Moreover, the new series differs from earlier series in another notable respect: it classifies two of the most commonly cited banking panics - 1884 and 1890 - as minor. Both the 1884 and 1890 banking panics were localized disturbances confined primarily to New York City.

\subsection{Inconsistencies in Earlier Series}

A comparison of my new series with earlier series reveals some major inconsistencies. Some series combined panics with other developments in financial markets. Others failed to distinguish among different types of financial panics. A few series even went so far as to incorrectly identify foreign banking panics as domestic ones.

To demonstrate this, consider table 3, which presents the new series on banking panics alongside the eight earlier series for the period 1825-1929. This is a particularly useful comparison since four of the panic series-Bordo-Wheelock, Reinhart-Rogoff, Gorton, and Wicker-explicitly refer to themselves as series on banking panics or banking crises. Entries with strikes through them are panic episodes noted in one of the eight panic series not included in the new series on banking panics. These episodes do not contain banking panics. I consider them one at a time.

1825 and 1847: In both 1825 and 1847, a banking panic occurred in England-not in the United States. The Bordo-Wheelock, Thorp, and Reinhart-Rogoff series list 1825 as a U.S. panic date and the Thorp series lists 1847 as a U.S. panic date. While serious banking panics did occur, they were confined to England in both cases. The reporting of the Niles Weekly Register in 1825 contains only a few reports of isolated bank failures in the U.S and the reporting of the Merchants' Magazine and Commercial Review in 1847 does not contain any accounts of bank runs, suspensions or failures in the U.S. There was no generalized panic in the U.S. in either year.

April 1864: One version of the Reinhart-Rogoff series lists April 1864 as a banking crisis; however, no banking panic occurred. Instead, a serious disturbance on stock markets erupted following the passage of a law in the U.S. senate designed to force a reduction in the price of gold. ${ }^{24}$ According to the press, the measure "excited the liveliest fears...the stock market, under the immense

\footnotetext{
${ }^{23}$ Because I am using three different newspapers over the 1825 to 1929 period, a useful check to make sure that the reporting is consistent across newspapers is to see if different newspapers in overlapping periods-periods in which more than one newspaper were in operation - identify the same banking panics. There are two overlapping periods: (1) April 1842 to 1849 (Niles Weekly Register and Merchants' Magazine) and (2) 1865 to 1869 (Merchants' Magazine and Commercial and Financial Chronicle). In the two overlapping periods, I arrive at the same results, regardless of which newspaper I use. Between April 1842 and 1849, both the Niles Weekly Register and the Merchants' Magazine identify just one minor banking panic: the minor banking panic in New Orleans in 1842. Between 1865 and 1869, both the Merchants' Magazine and the Chronicle do not identify any banking panics.

${ }^{24}$ Due to increased borrowing to finance wartime expenditures, the price of gold had seriously increased.
} 
pressure...underwent a severe revulsion." 25 In reporting the events of April 1864, the editors of the Merchants' Magazine described "one of the most severe revulsions of late years in the stock market." ${ }^{26}$ However, the crisis appears to have been confined entirely to the stock market: there were no reports of any bank runs, suspensions, or failures in April of 1864.

Oct 1896: The Gorton series lists October 1896 as a banking panic; however, no banking panic occurred then. The Commercial and Financial Chronicle did not report any banking panics in October 1896. Instead, a minor banking panic — confined entirely to Chicago, St. Paul and West Superioroccurred in December of that year. The panic was small in scope; only 4 banks suspended.

1914: Even though serious financial instability occurred, the events of the summer of 1914 do not constitute a banking panic — according to my definition — since bank runs, suspensions, and failures were avoided. The outbreak of war in Europe dramatically increased the demand for specie and caused a worldwide rush to liquidate stocks, resulting in the closing of the New York Stock Exchange on July 31, 1914. A few days later in early August, fears of a run on the U.S. banking system led to the issuance of emergency currency under the Aldrich-Vreeland Act. The Act flooded the country's banking system with additional currency to ward off a panic. The measure appears to have been successful: no banking panic materialized in $1914 .^{27}$

Five DeLong-Summers Panics: Five of the twelve DeLong-Summers panic quarters do not contain banking panics: 1896:01, 1896:03, 1898:02, 1903:02, and 1909:04. To verify this, I read the Commercial and Financial Chronicle during all of the DeLong-Summers panic quarters. Since no banking panics occurred, why were these five episodes classified as panics? Several of them satisfy the DeLong-Summers panic criterion of a quarter-to-quarter increase of more than one percentage point in the average commercial paper rate-a potentially important development in financial markets, but not necessarily an indicator of a financial panic. ${ }^{28}$

Twenty-One Kemmerer Panics: Table 3 makes it clear that the Kemmerer series should never be used or interpreted as a series on banking panics: more than two-thirds of Kemmerer's panic episodes do not contain banking panics. Eight of the twenty-nine Kemmerer panic episodes contain banking panicsSept 1873, May 1884, Nov 1890, May-Aug 1893, Dec 1896, July 1901, and Oct 1907-whereas the remaining twenty-one do not contain banking panics. To verify this, I read the Commercial and Financial Chronicle-Kemmerer's source in identifying panics-during all of Kemmerer's panic episodes. Since no banking panics occurred, why did Kemmerer classify these twenty-one episodes as panics? A reading of the Chronicle provides a hint: many of Kemmerer's episodes coincided with reports of instability in the stock market. This raises the possibility that Kemmerer combined banking

\footnotetext{
${ }^{25}$ Merchants' Magazine and Commercial Review, May 1864, “Commercial Chronicle and Review,” p. 364.

${ }^{26}$ Page 363.

${ }^{27}$ This episode is contained on the Gorton and Reinhart-Rogoff series. However, Reinhart and Rogoff acknowledge in a brief summary of the episode that a banking crisis was avoided in 1914: "a banking crisis was avoided by flooding the country with emergency currency to prevent hasty withdrawals" (Reinhart and Rogoff, p. Table A5-18).

${ }^{28}$ Three of these five episodes - 1896:1, 1896:3, 1898:2 - satisfy the criterion of a quarter-to-quarter increase in the commercial paper rate of more than one percentage point. Presumably, they were classified as panics on that basis. The other two panic quarters - 1903:2 and 1909:4 — do not satisfy the DeLong-Summers criterion of a quarter-toquarter increase of one percentage point in the commercial paper rate.
} 
panics with stock market disturbances in one series or that Kemmerer's panic series was intended to serve as a series on stock market panics, with these eight banking panic episodes simply coinciding with stock market panics. However, because Kemmerer never clearly explained what kind of financial disturbance he included as a panic, it is unclear which of these two interpretations most accurately applies to his series. Moreover, even if Kemmerer had intended his series as a series on stock market panics, it is unlikely that he constructed it in a consistent way. Kemmerer relied on the reporting of the Chroniclerather than on stock market indices or other quantitative evidence - to identify his episodes. Deciphering the magnitude of declines in stock prices or the magnitude of instability in stock markets from the qualitative reporting of the Chronicle is likely to be highly unreliable. This might, in part, explain the cautionary messages - outlined in section 1.3 - that Kemmerer provided regarding the accuracy of his series.

\subsection{Frequency of Banking Panics}

Table 4 presents the frequency of banking panics. Frequencies are calculated by dividing number of years by number of panics. To differentiate the pre-Federal Reserve era from the post-Federal Reserve era, I calculate pre-1914 and 1914 to 1929 frequencies.

Before 1914, major banking panics occurred at a rate of one major banking panic every 12.9 years and minor banking panics occurred at a rate of one minor banking panic every 6 years. It should be noted, however, that the occurrence of three major banking panics during the 1830's increases the rate of major banking panics - by contrast, the median number of years separating major banking panics is sixteen. Between 1914 and 1929, minor banking panics occurred at a rate of one every 3.5 years. No major banking panics occurred between 1914 and 1929.

The conventional wisdom on the historical frequency of panics is that the frequency of panics was high before 1914 and that the frequency dramatically decreased between 1914 and 1929 — that is, during the first fifteen years of the existence of the Federal Reserve. However, as it turns out, much of this was based on an unreliable panic series. According to my new series on banking panics, there is no evidence of a decline in the frequency of panics during the first fifteen years of the existence of the Federal Reserve.

The perception in the literature that panics before 1914 were frequent and recurring comes from the Kemmerer series. Using the Kemmerer series, Miron (1986) argues that major panics occurred at a rate of one every three years. If minor panics are included, then the rate-according to Miron-increases to more than one panic per year. ${ }^{29}$ Romer (1999) - also relying on Kemmerer's listing of panicsconcludes, "financial panics were ubiquitous before World War I." 30 Meltzer (2003), drawing on the findings of these earlier studies, writes in his History of the Federal Reserve, "financial panics... were much too frequent [before 1914]." ${ }^{31}$ However, for reasons previously described, the Kemmerer series

\footnotetext{
${ }^{29}$ Miron writes, "If only major panics are included, the frequency was slightly more than one every three years. Including minor panics raises the frequency to more than one per year" (p. 131).

${ }^{30}$ Page 38 .

${ }^{31}$ Page 9.
} 
presents an unreliable listing of panics, rendering any conclusions formulated on the basis of that series highly questionable.

Moreover, the perception in the literature that the frequency of financial panics decreased between 1914 and 1929 is also based on the Kemmerer series. It originates with Miron (1986), who used the Kemmerer series to document the incidence of panics prior to 1914. Between 1890 and 1908, Kemmerer identified six major panics, permitting Miron to conclude that the probability of having a major panic in a given year was 0.316. By contrast, Miron then claims that between 1915 and 1929, the banking system did not experience any financial panics. ${ }^{32}$ Using the pre-1914 frequency of major panics derived from the Kemmerer series, Miron calculates that the probability of going fourteen years — from 1915 to 1929 without a major panic was 0.005. On the basis of this evidence, Miron concludes that the Federal Reserve's policies of furnishing an elastic currency — one that could expand during seasons of high money demand and contract during seasons of low money demand - strengthened the nation's banking system to ward off panics, resulting in this purported dramatic reduction in the frequency of panics between 1914 and 1929. This claim has subsequently been picked up by others and is now widely circulated in the literature. $^{33}$

However, Miron's claim hinges on the Kemmerer series. According to my new series on banking panics, it was not uncommon for fifteen consecutive years to elapse without a major panic. Eighteen years separated the major banking panics of 1839 and 1857, sixteen years separated the major banking panics of 1857 and 1873, twenty years separated the major banking panics of 1873 and 1893, and fourteen years separated the major banking panics of 1893 and 1907. Moreover, the median number of years separating major banking panics between 1825 and 1914 was 16. Therefore, the absence of a major panic for fifteen consecutive years - from 1914 to 1929-provides no support for the claim that the frequency of panics decreased during the first fifteen years of the existence of the Federal Reserve. ${ }^{34}$ Prior to 1914, recurring periods of 14 to 20 years without a major banking panic were the norm.

Broadening the analysis to incorporate minor banking panics does not provide support to the claim of a reduction in the frequency of panics between 1914 and 1929. Between 1825 and 1914, minor banking panics occurred at a rate of one every 6 years. By contrast, between 1914 and 1929, minor banking panics occurred at a rate of one every 3.5 years. If anything, these results indicate that there was an increase — rather than a decrease — in the frequency of minor banking panics between 1914 and 1929.

\footnotetext{
32 "Between 1915 and 1933, the banking system experienced financial panics only during the subperiod 1929-33" (Miron, page 131).

${ }^{33}$ For example, Bordo (1989) writes, "financial panics in the United States before 1914 generally occurred at seasonal peaks in nominal interest rates...After 1914, however, the Fed extended reserve bank credit to accommodate seasonal credit demands, thereby considerably reducing the amplitude of the seasonal interest rate cycle and preventing any panics from occurring between 1914 and 1929" (page 40). Meltzer (2003) also references this: "In the 1920s, the Federal Reserve received credit for improving economic performance...Although the economy continued to experience relatively large cyclical fluctuations and many banks failed, old style financial panics did not return in the three recessions from 1920 through 1927” (page 9).

${ }^{34}$ The next major banking panic - the first one of the Great Depression — occurred in 1930, sixteen years after the founding of the Fed.
} 


\subsection{Seasonality of Major Banking Panics}

An additional result of the new series is the seasonality of major banking panics. Consider Table 5, which documents the seasonality of banking panics before the founding of the Federal Reserve. There is a strong tendency for major banking panics of this era to break out during the fall or spring. Six of the seven major banking panics - or 86\% — began in a fall or spring month. Four broke out during the fallthe Panic of 1833 (November), the Panic of 1839 (October), the Panic of 1873 (September), and the Panic of 1907 (October) - and two broke out during the spring - the Panic of 1837 (March) and the Panic of 1893 (May). The sole exception - the Panic of 1857 — began during the last week of August, but became more intense during the fall months of September and October. Thus, there is strong evidence that major banking panics were more likely to occur during particular seasons: six of the seven major banking panics began during the spring or fall. ${ }^{35}$

These results support the hypothesis that the Federal Reserve's policies to eliminate seasonal stringencies in the money market - the establishment of an elastic currency that could expand and contract when needed - had a stabilizing influence on the nation's banking system between 1914 and 1929. Even though it was noted in the previous section of this paper that the frequency of panics did not decline during the first fifteen years of the existence of the Federal Reserve, its policies still might have helped strengthen the nation's banking system to ward off panics. The true counterfactual- the incidence of panics from 1914 to 1929 without the Federal Reserve's policies-is unobservable. Nevertheless, the general tendency of major banking panics to occur during those seasons characterized by stringent monetary conditions before 1914 suggests that the establishment of an elastic currency following the founding of the Federal Reserve likely helped stabilize the banking system.

\subsection{Correlation with Downturns}

A final trend that merits attention is the strong correlation between major banking panics and downturns. Table 6 presents the behavior of the Davis Index of Industrial Production surrounding every major banking panic between 1825 and 1914. The Davis Index is the only consistent output series that spans the entire pre-WWI U.S. economy. Davis (2004) used 43 quantity-based annual series in the mining and manufacturing sectors to compile his index. According to Davis, these series "indirectly represent close to 90 percent of the value added produced by the U.S. industrial sector during the nineteenth century" (p. 1179). Consequently, it serves as a reliable measure of real economic activity. Its chief limitation is that it is available at only a yearly frequency.

Table 6 shows that the Davis index declines surrounding each panic episode. The correlation between major banking panics and downturns is clear. These results stand in stark contrast to those of DeLong and Summers (1986) who do not find a strong link between downturns and panics using their series.

\footnotetext{
${ }^{35}$ Minor banking panics were not much more likely to occur during the fall or spring: $53 \%$ broke out during the fall or spring, whereas $47 \%$ broke out during the summer or winter. See table 6.
} 
However, the existence of a correlation between panics and downturns does not prove that panics have real output effects since panics might be consequences-rather than causes - of downturns. To identify the output effects of panics, a stronger test is required.

\section{Part IV. The Macroeconomic Effects of Banking Panics}

Equipped with the new panic series, this section conducts a test to identify the output effects of major banking panics. The main problem in identifying the output effects of panics is the possibility that panics might be consequences - rather than causes - of downturns. To overcome this concern, I study the output effects of major banking panics that the reports of contemporary observers suggest were the result of idiosyncratic disturbances, as opposed to declining output conditions. I then investigate three related issues: (1) the role of panics as a source of economic instability before the founding of the Fed, (2) how downturns with major banking panics differed from downturns without them, and (3) whether the effects of panics persist over time.

\subsection{Development of the Empirical Test}

\section{$\underline{\text { Restriction of Test to Major Banking Panics }}$}

To begin, I limit my test on the real output effects of banking panics to major banking panics. I exclude minor banking panics due to data limitations. The existing historical series on real economic activity are available at a national level, making an assessment of the effect of major banking panics on aggregate output feasible. By contrast, an assessment of the real effects of minor banking panics, which tend to be more localized disturbances, would require regional data on output. Unfortunately, such data are unavailable throughout most of U.S. history. This does not mean that localized banking panics did not have significant real effects for the U.S. economy. However, any evidence of the output effects of localized panics would likely be muddled in national statistics on output, making a statistical analysis of the real effects of localized panics very noisy. As a consequence, I confine my test to major banking panics.

\section{The Identification Problem}

Table 6, which presents the behavior of the Davis Index of Industrial Production surrounding every major banking panic between 1825 and 1914, shows that there is a clear correlation between major banking panics and output declines. However, as noted earlier, this information by itself does not prove that panics have real output effects. If panics are products of recessions, then deteriorating economic conditions might be causing panics, rather than vice versa. Mitchell (1941) and Fels (1959) provide the main articulation of this hypothesis. ${ }^{36}$ They argue that major recessions cause panics. During downturns, business failures and declining fundamentals cause depositors to become alarmed that banks will suspend or fail. This precipitates a run to convert deposits into currency, thereby generating a panic. Under this

\footnotetext{
${ }^{36}$ Gorton (1988) terms this the Recession Hypothesis.
} 
specification, it would be misleading to attribute output declines to panics since panics would be products of downturns rather than causes. ${ }^{37}$

Unfortunately, data limitations for the pre-Great Depression era make this identification problem even worse. Many of the output series dating back to the 1800 s are available at only a yearly frequency, making it difficult to identify whether panics preceded downturns or occurred in the midst of downturns. ${ }^{38}$ If time series data on output were available at a greater frequency, it might be possible to identify the timing of panics in relation to the timing of output declines. If, for example, panics precede output declines, then it might be possible to conclude that panics caused the output declines, rather than vice versa. But in the absence of such data, this is not possible. ${ }^{39}$

As a consequence, to assess whether panics have real output effects, other evidence is required. If panics are caused by recessions, then it might be difficult to disentangle the output effects, if any, of a panic. However, if panics are caused by idiosyncratic disturbances, as opposed to declining output conditions, then it would be straightforward to identify the output effects of a panic. Under this latter scenario, a test of whether panics have real output effects is simply to see if real economic activity declines following the outbreak of these panics.

When a purely statistical analysis falls short, the potential benefits of drawing on other sources become especially useful. Of particular relevance, financial and economic newspapers from the 1825 to 1914 period contain detailed commentaries by economic observers that clarify many of the issues left unanswered by a strictly quantitative analysis. In many instances, the economic press isolate the panic's primary causes, making it easier to determine whether the panic was caused by a downturn or by some other disturbance.

Moreover, in the absence of more frequent time series data on output, the newspaper records are helpful in shedding light on the appropriate ordering of events. Did panics predate downturns or did they occur in the midst of declining economic conditions? According to the Mitchell and Fels framework,

\footnotetext{
${ }^{37}$ These issues are particularly relevant in the debate on the causes of the Great Depression. Friedman and Schwartz (1963) argue that a wave of banking panics turned a relatively normal downturn into a much more severe depression. However, Temin (1976) challenges the Friedman and Schwartz view, distinguishing between two possibilities:

"The assertion is that the banking panics turned a short depression into a sustained decline in national income. The question to be examined here is whether the banking panics were independent of the fall in income or a result of this fall" (p. 83)

Friedman and Schwartz place special emphasis on the banking panic of October 1930, the first major banking panic of the Great Depression, arguing that "in October 1930, the monetary character of the contraction changed dramatically" (p. 308). As a result, Temin focuses his analysis on this panic episode. He concludes that agricultural distress - which was, he argues, a component of the depression - caused the banking panic of 1930. In Temin's view, the banking panics of the Great Depression were consequences - rather than causes - of the depression.

${ }^{38}$ The Miron-Romer Index of Industrial Production, the first, reliable monthly series of industrial production, begins in 1884. Monthly data on pig iron production begin in 1877. Monthly data on bank clearings begin in 1854 and have often been used as an indicator of business activity. However, they are not useful for the purposes of this paper since bank clearings are a measure of banking activity, rather than a direct measure of output. Using bank clearings to draw conclusions regarding the output effects of banking panics could therefore lead to spurious results.

${ }^{39}$ Moreover, while the availability of output data at a greater frequency would certainly be helpful in determining whether panics preceded downturns, such information, by itself, might not be enough to solve the identification problem since bad news about future output conditions could generate a panic even before output begins to decline.
} 
major recessions cause panics because depositors become alarmed by declining fundamentals. In this framework, newspaper reports should reflect these deteriorating economic conditions and serve as a signal to depositors that fundamentals are declining. An examination of the news reports of economic conditions provides an assessment of how the public viewed the state of the economy surrounding each panic episode. According to the press, were economic conditions prosperous on the eve of the panic? Or were they declining? Did the press describe deteriorating economic fundamentals? Or was the state of the economy described as strong?

\section{The Test}

To overcome this identification problem, I conduct the following test. I read the newspaper records surrounding every major banking panic between 1825 and 1914 to identify those panics that were caused by idiosyncratic disturbances, as opposed to declining output conditions. I then use these episodes to empirically identify the output effects of panics. The test of whether panics have real output effects is simply to see if real economic activity declines following the outbreak of these panics. ${ }^{40}$

The newspapers used in this study are contemporary financial and economic periodicals from the 1825-1914 period. In particular, I employ the following newspapers: Niles Weekly Register (1825-1849), The New York Commercial Advertiser (1825-1857), the Merchants' Magazine and Commercial Review (1839-1869) and The Commercial and Financial Chronicle (1865-1914). These periodicals were among the leading economic and financial newspapers of their day.

I read the newspaper records surrounding major banking panics to accomplish two goals: (1) to identify the causes of panics and (2) to identify the state of the economy when the panic broke out. The reasons for this are simple. In assigning causes to panics, contemporary observers may be able to pinpoint the forces that precipitated depositor anxiety and that led to a panic. In reporting the state of the economy, the press may be able to clarify whether there were indications of a major recession on the eve of the outbreak of panic. Both pieces of information are helpful in determining whether a panic was caused by a downturn or by some other disturbance.

The newspaper records are incredibly useful in identifying the causes of panics. Descriptions of events leading up to panics and reports by contemporary economic observers help to identify a panic's primary causes. Moreover, these records provide a gauge of market participants' contemporaneous beliefs regarding the causes that led to a panic. Did depositors panic because there were growing signs of a depression or did they panic in response to some other disturbance?

In addition, it is straightforward to determine how the press perceived the state of the economy when a panic broke out. Many of the newspapers used in this study contained sections that described general macroeconomic trends on a regular basis: "The Commercial Epitome" in the Commercial and Financial Chronicle, "The Commercial Chronicle and Review" in the Merchants' Magazine and Commercial Chronicle, and "Review of the Market" in the New York Commercial Advertiser. Given the lack of data available to the economic press of the $19^{\text {th }}$ and early $20^{\text {th }}$ centuries, reporting of general

\footnotetext{
${ }^{40}$ The test is similar in spirit to the "narrative approach" of Romer and Romer (1989) that seeks to identify the real effects of monetary policy.
} 
macroeconomic trends clearly lacked the precision to which we are accustomed today. However, the economic press did have correspondence with the leading industrial and manufacturing centers of the country, allowing them to make broad generalizations regarding macroeconomic developments. Most importantly, the reporting by the press reveals the kinds of signals being sent to the public regarding the overall health of the economy. If depositors became alarmed that a recession would cause banks to fail, then such signals would have been present in the news reporting.

Therefore, I employ newspapers records to separate banking panics that were caused by downturns from those that were caused by other disturbances. However, since I will be relying on newspaper accounts, there may be varying degrees of certainty across panic episodes. In some cases, the causes of a panic might be clear and obvious, whereas in other cases, the causes might be more ambiguous. Hence, to reflect these varying degrees of certainty, I will be classifying panics along a two-dimensional scale. The scale ranges from 1 to 3 . Figure 1 presents a visual representation of this scale.

On the first dimension, I classify panics according to reported causes. I read the newspaper records surrounding banking panics to identify the events or forces that contemporary observers cited as primary causes of the panic. If the newspaper records identify an event unrelated to output fluctuations as the primary cause of the panic, then I assign the panic a 3. Examples of events that might precipitate a panic, but that are likely to be unrelated to output fluctuations include political decisions, the failure of a mismanaged bank, and international contagion. A political decision that causes a change in market expectations regarding the stability of the banking sector, the failure of a mismanaged bank and a subsequent contagion of fear generated in the aftermath of such a failure, or a panic abroad that triggers financial instability at home are all events that might generate a panic, but that are likely to be unrelated to movements in domestic output conditions. If the newspaper records identify any of these eventspolitical decisions, failure of a mismanaged bank, or international contagion - as the primary cause of the panic, then I assign the panic a 3.

Figure 1. Scale Dimension 1 - Reported Causes

1 2

Primary Cause: Event Related to Output Fluctuations --Downturn

1

Depression/Recession on the Eve of the Outbreak of Panic
Mixed Causes: Records Cite a Downturn as well an Event Unrelated to Output Fluctuations (political decisions, failure mismanaged bank, intl. contagion)

Dimension 2 - State of the Economy

2

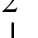

Primary Cause: Event Unrelated to Output Fluctuations --Political Decision --Failure of Mismanaged Bank --International Contagion 
By contrast, if the newspaper records identify output fluctuations as the primary cause of the panic, then I assign the panic a 1. A banking panic caused by depositor anxiety that a major recession will cause banks to fail or suspend would be a prime example of a panic that would receive a 1 on the first dimension of the scale.

On the second dimension of the scale, I classify panics according to the state of the economy when the panic broke out. I read the descriptions of economic conditions on the eve of the outbreak of panic. ${ }^{41}$ If the newspaper records characterize economic conditions as "prosperous" on the eve of the outbreak of panic, then I assign the panic a 3. If the newspaper records characterize the state of the economy as in "depression" or in "recession" on the eve of the outbreak of panic, then I assign the panic a $1 .{ }^{42}$

Moreover, on both dimensions, there is an intermediate category 2, which is reserved for ambiguous situations in which the newspaper records are not definitive in assigning causes or in characterizing the state of the economy. If the newspaper records identify both a downturn as well as other events that are unrelated to output fluctuations as primary causes of the panic, then the panic is assigned a 2 on the first dimension. If the newspaper records do not clearly characterize economic conditions either as "prosperous" or as in "depression/recession," then the panic is assigned a 2 on the second dimension

Lastly, in situations where the newspaper records are uninformative in identifying causes or in characterizing the state of the economy, I simply exclude the panic from the ranking. This occurs when the newspaper records do not seem to know what caused the panic and are in widespread disagreement or when the newspaper records simply do not contain descriptions of the state of the economy on the eve of the outbreak of panic.

\subsection{The Classification}

Between 1825 and 1929, there were seven major banking panics: 1833, 1837, 1839, 1857, 1873, 1893, and 1907. Table 7 presents the classification of these major banking panics on the scale. Three important observations should be noted. First, three banking panics - the panics of 1833, 1857, and 1873 - received a 3 on both dimensions of the scale - that is, they did not break out in the midst of a

\footnotetext{
${ }^{41}$ To determine whether the press reported positively or negatively on the state of the economy before the outbreak of panic, I read the following articles for the two months immediately preceding the panic: "The Commercial Epitome" in the Commercial and Financial Chronicle, "The Commercial Chronicle and Review" in the Merchants" Magazine and Commercial Chronicle, and "Review of the Market" in the New York Commercial Advertiser.

${ }^{42}$ The reason for classifying panics on this second dimension is simple: it provides an additional filter to separate panics that may have been caused by downturns from those that were not. For example, consider a panic that broke out in the midst of declining economic conditions. If contemporary observers attributed the panic to an event unrelated to these declining output conditions, then the panic would receive a 3 on the first dimension of the scale. However, the panic's occurrence in the midst of declining economic conditions calls into question whether contemporary observers were accurate in dismissing the role of deteriorating economic activity in aggravating depositor unrest. Therefore, classifying panics according to the state of the economy when the panic broke out provides an additional criterion to weed out panics that may have been caused by output fluctuations from those that were not.
} 
downturn and they were not caused by output fluctuations, according to the newspaper records. These episodes serve as ideal candidates to identify the output effects of banking panics.

Second, no banking panics received a 1 on the first dimension of the scale-that is, none were attributed exclusively to a downturn. However, that should not be interpreted to mean that none of these banking panics were caused by downturns. Panics that received a 2 on the first dimension - the Panic of 1907-fell on the median category, meaning that the newspaper records identified both a downturn and another disturbance as causes. Moreover, even though the Panic of 1893 received a 3 on the first dimension of the scale, it received a 1 on the second dimension because the newspaper records reported deteriorating economic conditions when the panic broke out, raising the possibility that declining output conditions played a role in the outbreak of that panic.

Third, the newspaper accounts were particularly unhelpful in classifying two of the major banking panics - the panics of 1837 and 1839. Contemporary observers were in widespread disagreement regarding the causes of these panics. In addition, the press failed to provide descriptions of economic conditions on the eve of the outbreak of these panics. For these reasons, I omit these two panics from the scale.

In this section, I describe the classification of panics on this scale. Due to space constraints, I present a condensed version. For a more detailed treatment of each panic and for more extensive documentation, see section A.3 of the appendix.

\section{Dimension 1: Reported Causes}

\section{Panic of 1833: Political Decision}

According to the newspaper records, a political decision - the withdrawal of the government deposits from the Bank of the United States - caused the Panic of 1833. Chartered in 1816, the Bank of the United States served as the country's fiscal agent, promoted a more uniform national currency, and aided the economy in times of distress. Accordingly, many historians view the Bank of the United States as a quasi-central bank. However, for ideological reasons, President Andrew Jackson was a consistent opponent of the Bank of the United States throughout the course of his presidential administration. As a consequence, Jackson decided to remove the government deposits from the Bank of the United States, beginning on October 1, 1833. Shortly thereafter, confidence in the Bank of the United States and in the overall banking system became impaired, precipitating runs. Fears that the country's quasi-central bank would be weakened and that the nation's banking system might be destabilized were widely reported by the press. The newspaper records attribute the panic's origins to the destruction of "aggregate individual confidence" 43 following the removal of the government deposits from the Bank of the United States.

\footnotetext{
${ }^{43}$ New York Commercial Advertiser, Jan 6, 1834, "Correspondence for the Commercial Advertiser".
} 
Panic of 1837 and Panic of 1839: Records in Widespread Disagreement

The newspaper records were in widespread disagreement regarding the causes of the Panics of 1837 and 1839. Indeed, a range of causes was provided for both panics. For the Panic of 1837, some reports identified political decisions of the Jackson administration as causes, whereas others identified years of unstable activity in the banking sector as the primary cause. For the Panic of 1839, some reports identified misguided decisions of banking authorities as the cause of the panic, whereas others identified the weak economic conditions prevailing since the prior panic as the primary cause. In 1839, the editors of the Niles Weekly Register described the uncertainty they felt regarding the causes of the panic, "we are too much in the dark as to the immediate cause of the catastrophe, to venture a decided opinion on the causes which produced it." 44

\section{Panic of 1857: Failure of Mismanaged Bank}

The catalyst for the Panic of 1857 was the failure of the Ohio Life Insurance Company. Its failure was attributed to mismanagement and fraudulent activities. ${ }^{45}$ The collapse of this banking firm triggered the panic. The Ohio Life was considered one of the most reputable firms in the nation and initially, the cause of its failure was unknown. Its demise shocked the financial community and sparked runs on banks throughout the country. Over the succeeding weeks, fear spread and the panic gained in intensity. The news reports identify this contagion of fear following the failure of the Ohio Life as the cause of the panic.

\section{Panic of 1873: International Contagion}

The panic of 1873 had its origins abroad. In May, a stock market crash in Vienna caused European investors to dispose of their holdings of American securities, and especially, their holdings of railroad bonds, the leading American security traded internationally. As a consequence, domestic markets became overloaded with railroad bonds to such a large degree that new bond sales could no longer be realized, cutting off the resources of many railroad companies and forcing several of them to default on interest payments. Over time, this precarious financial situation, along with the failure of some minor firms associated with the railroad sector, generated a feeling of distrust toward the railroad industry. On September 18, 1873, the failure of Jay Cooke and Company, a prominent banking company with connections to several railroad companies, unleashed the panic. The newspaper records identify international contagion as the cause of the panic: international forces - the unloading of American railroad securities abroad - produced financial instability at home, resulting in a panic. ${ }^{46}$

\footnotetext{
${ }^{44}$ Niles Weekly Register, Oct 26, 1839, “Suspension of Specie Payments," p. 139.

${ }^{45}$ Edward Ludlow, the director of its New York office, loaned \$2 million, an amount that equaled the firm's capital, to several railroad companies, with a significant proportion being loaned to the struggling Cleveland \& Pittsburgh road. Following the bank's suspension, Charles Stetson, the president of the company, seemed to be unaware of Ludlow's activities and immediately launched an investigation. The extent of Ludlow's mismanagement is still unclear-charges that his activities involved fraud and that he stole money for his own devices were leveled against him.

46 "Report of the Comptroller of the Currency" in the Commercial and Financial Chronicle, Dec 6, 1873, p. 767768. See the appendix for more details.
} 


\section{Panic of 1893: Political Decision}

The Commercial and Financial Chronicle attributed the outbreak of panic in 1893 to the Sherman Silver Purchase Act of 1890, a measure passed by pro-silver forces in the U.S. Congress. The Act's intended objectives centered on curbing deflation to improve the plight of debt-laden farmers; however, according to the press, it failed to achieve its goals and instead, served primarily to weaken the U.S. commitment to the gold standard. The Sherman Silver Act mandated that the U.S. government purchase 4.5 million ounces of silver bullion every month with notes that could be subsequently redeemed in either gold or silver - a requirement that over time, impaired the government's gold reserves and sparked doubts at home and abroad that the U.S. would remain on the gold standard. Fears that the U.S. would be forced onto a silver standard became self-fulfilling as foreign investors began withdrawing gold from the country in large quantities. Gold exports, coupled with growing anxiety over the U.S. commitment to the gold standard, undermined confidence in the nation's banking system, resulting in runs by nervous depositors that led to a panic. The newspaper records identify the Sherman Silver Purchase Act—a political decision - as the cause of the panic. ${ }^{47}$

\section{Panic of 1907: Mixed Causes (Downturn or Mismanagement/Fraudulent Banking Activity)}

The actions of a group of New York City financiers, with controlling interests over several banks, triggered the panic of 1907. The group misappropriated bank funds to speculate on rising copper prices. The gamble proved to be a mistake. Copper prices collapsed and news of these events triggered runs on the banks implicated in the speculation. Rumors that other banks and trust companies might be connected to the speculators unsettled public confidence and a panic quickly spread throughout the city. Within a few days, the panic spanned most of the country. What caused the panic? The Commercial and Financial Chronicle identified two causes. For one, the Chronicle identified this fraudulent banking activity as a cause. But for another, the Chronicle also identified growing signs of a recession as an additional force that undermined confidence. The editors of the Chronicle wrote, "The more immediate causes for the upheaval deserve narration here...There were...multiplying evidences of a reaction in the iron and steel trades and of recession in general business." 48

\section{Dimension 2: State of the Economy}

\section{Panics of 1833, 1857, and 1873: Prosperity}

Prior to the outbreak of the Panics of 1833, 1857, and 1873, economic conditions were prosperous, according to the newspaper records. On the eve of the Panic of 1833, commentators were describing "the unexampled prosperity of the year" 49 and were reporting, "every thing has the appearance that an early

47 Commercial and Financial Chronicle, Aug 12, 1893, "The Financial Situation," p. 232; Commercial and Financial Chronicle, Aug 5, 1893, "Is It the Balance of Trade or the Silver Law, p. 199.

${ }^{48}$ Commercial and Financial Chronicle, Nov 2, 1907, "Review of October," p. 22.

${ }^{49}$ New York Commercial Advertiser, Wed Oct 2, 1833, p. 2. 
and extensive fall business will be done." ${ }^{50}$ On the eve of the Panic of 1857, the Merchants' Magazine noted, "the country continues prosperous," ${ }^{51}$ and the New York Commercial Advertiser reported, "The general business of the country is in a good condition, presenting both present and prospective, a most healthy appearance. $" 52$ On the eve of the Panic of 1873, the newspaper records noted, "business has been large and a cheerful tone pervades mercantile circles, ${ }^{, 53}$ and the Comptroller of the Currency reported, "there were in almost every direction evidences of prosperity." 54 Indeed, by all accounts, economic conditions were prosperous prior to the outbreak of these panics. ${ }^{55}$

\section{Panics of 1893 and 1907: Depression/Recession}

Prior to the outbreak of the Panics of 1893 and 1907, economic conditions were declining, according to the newspaper records. On the eve of the outbreak of the Panic of 1893, there were reports of many business and mercantile failures and the Commercial and Financial Chronicle made general references to an "existing depression." 56 On the eve of the outbreak of the Panic of 1907, there were reports of large increases in commercial failures and the press made frequent references to an "existing depression",57 and to a "recession in business." occurred in the midst of a downturn.

\section{Panics of 1837 and 1839: No Clear Descriptions}

In contrast to the reporting of other panics, the press failed to provide descriptions of economic conditions on the eve of the outbreak of these two panics. The section in the New York Commercial Advertiser that described economic conditions — the "Review of the Market" — was discontinued in 1837 and in 1839.

\subsection{The Effect of Banking Panics on Output and Prices}

Equipped with my classification of panics, I analyze the impact of banking panics on output. I estimate the relationship between banking panics and output under a variety of restrictions. Then, I investigate the impact of banking panics on inflation and the price level.

\section{$\underline{\text { Output }}$}

Methodology. To determine how output behaves following banking panics, I regress output growth on a constant, lagged values of output growth, a panic dummy and lagged panic dummies. I include

\footnotetext{
${ }^{50}$ New York Commercial Advertiser, Aug 17, 1833, "Review of Market.

${ }_{51}^{51}$ Merchants' Magazine and Commercial Review, "Commercial Chronicle and Review," September 1857, p. 325.

52 "Cincinnati Gazette of Tuesday, Aug 25" in New York Commercial Advertiser, August 27, 1857.

${ }^{53}$ Sept 13, 1873, Commercial and Financial Chronicle, "Commercial Epitome," p. 358.

54 "Report of Comptroller of the Currency" in the Commercial and Financial Chronicle, Dec 6, 1873, p. 767-768.

${ }_{56}^{55}$ For more accounts, see the appendix.

${ }^{56}$ Commercial and Financial Chronicle, June 10, 1893, "The Financial Situation," p. 946 and Commercial and Financial Chronicle, May 13, 1893, "The Depression in the Iron and Steel Trades," p.775.

${ }^{57}$ Commercial and Financial Chronicle, Oct 5, 1907, "The Financial Situation," p. 826-8.

${ }^{58}$ Commercial and Financial Chronicle, Nov 2, 1907, "Review of October," p. 22.
} 
lagged values of output growth to model the normal behavior of output. I include contemporaneous and lagged panic dummies to measure the direct impact of a panic on output growth. To measure output, I use the Davis Index of Industrial Production.

I estimate the following regression:

$$
\Delta y_{t}=a_{0}+\sum_{k=0}^{3} b_{k} P_{t-k}+\sum_{j=1}^{3} c_{j} \Delta y_{t-j}+e_{t}
$$

where $y$ is the log of the Davis Index of Industrial Production and $\mathrm{P}$ is a panic dummy. ${ }^{59}$ I estimate three different specifications of the above regression, with each specification corresponding to a distinct restriction on the panic dummy variable. In the first specification, I include panics that received a 3 on the first dimension of the scale in the panic dummy, in the second, I include panics that received a 2 or a 3 on the first dimension and in the third, I include only those panics that received a 3 on both dimensions of the scale. The first specification presents the baseline case in which all panics that received a 3 on the first dimension of the scale - those that the newspaper records attribute to events unrelated to output fluctuations - are included in the panic dummy variable. The second specification takes into account the possibility that panics that received a ranking of 2 on the first dimension of the scale were, in fact, not caused by output fluctuations. The third specification presents the most restrictive case in which only panics that received a 3 on both dimensions of the scale - those that did not break out in the midst of a downturn and that were not caused by output fluctuations, according to the newspaper records-are included in the panic dummy. The sample period is 1825 to 1915 , the final year of the Davis Index of Industrial Production.

Results. Table 8 presents the estimates. In all three specifications, the coefficients on the first lag of the panic dummy are negative and statistically significant. The coefficient is -0.102 in specification 1 , -0.130 in specification 2 , and -0.091 in specification 3 , indicating that output growth declines by approximately nine to thirteen percentage points in the year following a major banking panic. The respective t-statistics are $-2.86(\mathrm{p}$-value $=0.005),-4.30(\mathrm{p}$-value $<0.001)$, and $-2.14(\mathrm{p}$-value $=0.035)$.

The impulse response functions implied by the estimated regressions are shown in figure 2 . They map out the implied response of output to a unit shock in the panic dummy variable. The figures contain one standard error bands. The impulse response functions show that panics have large and significant effects on output. In the contemporaneous year, output remains roughly constant: it increases slightly in the third impulse response function - an increase that is statistically insignificant from zero-and decreases modestly in the first and second impulse response functions. However, in the year following the panic-year 1, there is a large decline in output: 13.3 percent according to the first impulse response function, 15.5 percent according to the second, and 8.3 percent according to the third. The impact

\footnotetext{
${ }^{59}$ This empirical framework can be thought of as a VAR with a single variable (log change in output) and with an exogenous variable (the panic dummy). It is similar to the framework used by Romer and Romer $(1989,2004)$ to identify the effects of monetary policy and to the framework used by Ramey (2008), Ramey and Shapiro (1998), and Romer and Romer (2008) to identify the effects of fiscal policy.
} 
remains fairly constant in years 2 and 3, decreasing slightly in year 2, but then increasing again in year 3 . The results are robust across all three specifications. ${ }^{60}$

Case Studies: The Panics of 1893 and 1907. The first reliable monthly series of industrial production - the Miron-Romer Index of Industrial Production-is available beginning in $1884 .{ }^{61}$ It permits an assessment of how output behaves in the months surrounding a panic - an assessment that is not possible using an annual index.

The Miron-Romer index spans two major banking panics: the panics of 1893 and 1907. Tables 9 and 10 present the seasonally adjusted Miron-Romer index of industrial production for the six months surrounding these two panics. The panic months are in bold. According to the newspaper records documented in section 4.2, there were reports in the press of declining economic conditions on the eve of the outbreak of both of these panics. There is some evidence of this in Tables 9 and 10. In April 1893, the month before the panic of 1893, industrial production declined by $0.97 \%$ and in August and September of 1907, the two months prior to the panic of 1907, industrial production declined by $1.27 \%$ and $2.02 \%$, respectively.

However, in both 1893 and 1907, there was a sharp increase in the rate of decline in industrial production during the panic months. During the panic of 1893, industrial production declined by $2.01 \%$ in May, $1.22 \%$ in June, $4.13 \%$ in July, and $2.89 \%$ in August. During the panic of 1907, industrial production declined by $3.45 \%$ in October and $4.45 \%$ in November. Moreover, following both of these panics, there was a relatively continuous decline in industrial production for the next six months, with the exception of one or two months. Furthermore, the cumulative declines were large. From April 1893 to February 1894, industrial production declined by $16 \%$ and from September 1907 to May 1908, industrial production declined by $17.4 \% .^{62}$

A Monthly Measure of Output. A monthly output series - the Long Index of Urban Constructionis available beginning in 1868. It measures building construction in thirty-five major cities. In his work Building Cycles and the Theory of Investment, Long (1940) argues that building was a leading investment goods industry in the $19^{\text {th }}$ and early $20^{\text {th }}$ centuries and as a consequence, that his series can be used as a proxy for investment. ${ }^{63}$ At the very least, the index is a reliable measure of construction, an important indicator of real economic activity.

The regression I use to estimate the monthly impact of banking panics on output is:

\footnotetext{
${ }^{60}$ To ensure that these results hold across a variety of specifications, I conduct several additional robustness checks. First, including the Panic of 1837 and the Panic of 1839 - the two panics excluded from my ranking-in the panic dummy does not change the results in any of the three specifications. If anything, the results become more significant with their inclusion. Second, using a VAR with two variables - panic dummy and log change in output - as opposed to the regression framework specified above produces the same results. The impulse response functions of output to a shock in the panic dummy are similar to those in Figure 2-that is, they show large, statistically significant declines in output in year 1, with the impacts remaining fairly constant in years 2 and 3 . By contrast, the impulse response functions of the panic dummy to a shock in log output are insignificant.

${ }^{61}$ The Index comes from Miron-Romer (1990).

${ }^{62}$ These basic results hold with non-seasonally adjusted data.

${ }^{63}$ Grossman (1993) adopts this interpretation.
} 


$$
\Delta \text { LongIndex }_{t}=a_{0}+\sum_{k=0}^{24} b_{k} P_{t-k}+\sum_{i=1}^{24} c_{j} \Delta \text { LongIndex }_{t-i}+\sum_{j=1}^{11} d_{j} D_{j t}+e_{t}
$$

where LongIndex is the log of the Long Index of Urban Construction, the $\mathrm{D}_{\mathrm{j}}$ 's are monthly dummies, and $\mathrm{P}$ is a dummy variable that equals one in the month in which a banking panic breaks out. I include 24 lags of the panic dummy to measure the lagged effects of the panic. I estimate two different specifications of the regression. In the first specification, I include panics that received a 3 on the first dimension of the scale, and in the second specification, I include panics that received a score of 2 or 3 on the first dimension of the scale. I do not include a regression that restricts the dummy variable to panics that received a 3 on both dimensions of the scale since only one banking panic satisfies this criterion between 1868 and 1914.

The estimates are presented in table 11. In both regressions, the coefficients of the first several lags of the panic dummy are negative, large, and in most cases, significant. In the first regression, the coefficients for the contemporaneous month and lags $1,2,3$, and 4 are -0.283 ( $\mathrm{t}$-stat $=-1.68),-0.335$ ( $\mathrm{t}$ stat $=-1.99),-0.849(\mathrm{t}-\mathrm{stat}=-5.04),-0.454(\mathrm{t}-\mathrm{stat}=-2.63)$, and $-0.224(\mathrm{t}-\mathrm{stat}=-1.29)$, respectively. In the second regression, the coefficients are $-0.218(\mathrm{t}-\mathrm{stat}=-1.61),-0.278(\mathrm{t}-\mathrm{stat}=-2.05),-0.649(\mathrm{t}-\mathrm{stat}=$ 4.76), $-0.339(\mathrm{t}-\mathrm{stat}=-2.43)$, and $-0.312(\mathrm{t}$-stat $=-2.23)$, respectively.

Figure 3 presents the impulse response functions. They show the cumulative impact of a major banking panic, along with one standard error bands. The impulse response functions show that panics have rapid effects. Output declines to its lowest level two months after the panic: a $65.5 \%$ decline according to the first specification and a 55.8\% decline according to the second. Output then increases slightly for a few months, but then hovers at roughly the same level for the remainder of the period, fluctuating within a relatively narrow band.

\section{$\underline{\text { Prices }}$}

In addition to the output effects of panics, I evaluate the impact of a banking panic on inflation and the price level. My methodology for prices is similar to the one for output. In particular, I estimate the following regression:

$$
\Delta \text { price }_{t}=a_{0}+\sum_{k=0}^{12} b_{k} P_{t-k}+\sum_{i=1}^{12} c_{j} \Delta \text { price }_{t-i}+\sum_{j=1}^{11} d_{j} D_{j t}+e_{t}
$$

where price is the log of the USA Annalist Wholesale Price Index, P is a panic dummy variable, and the D's are monthly dummies. The sample period is 1854 , the first year included in the USA Annalist Wholesale Price Index, to $1914 .{ }^{64}$ I estimate three different specifications of the above regression, with each specification corresponding to a distinct restriction on the panic dummy variable. In the first specification, I include panics that received a 3 on the first dimension of the scale, in the second, I include panics that received a 2 or 3 on the first dimension, and in the third, I include only those panics that received a 3 on both dimensions.

\footnotetext{
${ }^{64}$ The price data come from globalfinancialdata.com. The Index incorporates the wholesale prices of twenty-five commodities. It begins in 1854 and ends in 1940.
} 
The estimates are shown in table 12. Eight of the twelve coefficients of the lagged panic dummies are negative in the first specification, nine are negative in the second, and seven are negative in the third. The coefficient of the panic dummy is largest and most significant in month two in all three specifications: $-0.041(\mathrm{t}$-stat $=-3.47),-0.033(\mathrm{t}-\mathrm{stat}=-3.24)$, and $-0.048(\mathrm{t}-\mathrm{stat}=-3.25)$, respectively.

Figure 4 shows the cumulative impact of a banking panic on the wholesale price index, along with one-standard error bands. There is a rapid decline in the price level in the immediate months succeeding the panic. The decline slows down over time, but continues over the course of a year. The impacts at month 12 are $-13.1 \%,-11.2 \%$, and $-12.5 \%$ for the three specifications, respectively.

\subsection{Panics as a Source of Output Volatility, 1825-1914}

In assessing the determinants of historical changes in output variability, DeLong and Summers (1986) conclude that financial panics were not a significant source of economic instability prior to World War II:

"The view that financial panics were a principal cause of economic instability before World War II does not seem to be strongly supported. This finding weakens the monetarist argument linking output variability to erratic monetary growth by showing that relatively little of the variability in output observed before World War II can be linked to exogenous changes in the money stock" (DeLong and Summers, p. 692-3)

They base this conclusion on their finding that no more than a small portion of the variance in output between 1890 and 1910 can be attributed to financial panics. However, their findings depend on their panic series.

According to my new series, how important were panics as a source of economic instability? First, consider the pre-WWI period. The Davis Chronology of Business Cycle Turning Points provides a useful indicator for this period. Davis (2006) isolates fifteen turning points-fifteen downturns - between 1825 and 1915 using the Davis Index of Industrial Production. Table 13 presents the Davis Chronology.

Seven of these fifteen cycles — or 47 percent — contained major banking panics: 1833-1834, 1836$1837,1839-1840,1856-1858,1873-1875,1892-1894$, and 1907-1908. This suggests that banking panics either caused or - at the very least - seriously aggravated nearly half of all business cycle downturns between 1825 and 1914. If I exclude the three cycles contained within a major war - the two Civil War cycles from 1860 to 1861 and 1864 to 1865 and the World War I cycle from 1913 to 1914, then seven of the twelve non-war downturns - or 58 percent — contained major banking panics.

An alternative measure of the role of panics as a source of output volatility is the $\mathrm{R}^{2}$ in a regression that includes a panic dummy equal to one in the year in which a major banking panic breaks out, three lagged panic dummies, and three lagged log changes in output (measured using the Davis Index) as righthand side variables and that uses the log change in output as the left-hand side variable. The $\mathrm{R}^{2}$ in such a regression is 0.28 , indicating that roughly $28 \%$ of the variation in the growth rate of output can be

explained by the right-hand side variables. By contrast, the $\mathrm{R}^{2}$ in a regression that excludes the contemporaneous and lagged panic dummies — but otherwise remains the same - is 0.01 .

These results suggest that banking panics were a substantial source of output volatility in the 85 years prior to the founding of the Federal Reserve. DeLong and Summers are not justified in dismissing 
the role of financial panics as a cause of economic instability before World War II. If anything, the presence of major banking panics in nearly half of all business cycle downturns prior to WWI and their reoccurrence during the Great Depression - the sharpest downturn in U.S. history-suggest that panics were a significant source of economic instability throughout much of U.S. history. ${ }^{65}$

\subsection{Downturns with Major Banking Panics versus Downturns without Major Banking Panics}

Equipped with an accurate listing of when major banking panics occurred and with the Davis Chronology, I am also able to examine how downturns with major banking panics differed from downturns without them. Table 14 compares downturns with major banking panics from downturns without major banking panics on three dimensions: severity (the percentage decline in output from peakto-trough), the length of the downturn (the length of time from peak-to-trough), and the length of recovery (the length of time output took to recover from its trough back to its pre-downturn peak level). The table reports averages for the entire 1825-1914 period. It also presents averages for the pre-Civil war and postCivil war sub-periods. Because wartime conditions represent special economic circumstances that may have their own unique features, the table omits the three downturns that occurred in the midst of major wars - that is, the two downturns during the Civil War (1860-1861 and 1864-1865) and the downturn at the beginning of World War I (1913-1914).

Between 1825 and 1914, on average, downturns with major banking panics were more severe and slightly longer than downturns without major banking panics and output recoveries were longer for downturns with major banking panics than output recoveries for downturns without major banking panics. For downturns with major banking panics, the average percentage decline in output was $7.9 \%$, the average length of time from peak-to-trough was 1.4 years, and the average length of recovery was 1.7 years. For downturns without major banking panics, the average percentage decline in output was $4.8 \%$, the average length of time from peak-to-trough was 1.2 years and the average length of recovery was 1 year.

However, closer inspection of Table 14 reveals that these results are driven almost entirely by the post-Civil War period. Before the Civil War, downturns with major banking panics were not, on average, more severe than downturns without them and the average length of recovery was the same for both downturns with major banking panics and downturns without them. By contrast, after the Civil War, downturns with major banking panics were on average more than twice as severe as downturns without major banking panics and output recoveries for downturns with major banking panics were two-to-three times the length of output recoveries for downturns without major banking panics. Indeed, in the postCivil War era, for downturns with major banking panics, the average percentage decline in output was $12.3 \%$ and the average length of recovery was 2.7 years, whereas for downturns without major banking panics, the average percentage decline in output was $4.5 \%$ and the average length of recovery was 1 year.

Why do these strong differences exist in the post-Civil War era and not in the pre-Civil War era? One hypothesis is that structural changes to the U.S. economy over time- the transformation of an

${ }^{65}$ These results also indicate that the avoidance of banking panics after 1933 deserves some credit for improved macroeconomic stability in the postwar period. 
agricultural economy to a more industrial one or a greater reliance on bank credit-rendered the U.S. economy more vulnerable to disruptions in the banking sector. The hundred years prior to the Great Depression was a period of dramatic economic transformation; it is highly plausible that changes to the U.S. economy increased the susceptibility of the real economy to banking panics over time.

\subsection{Trend and Level Effects}

How long do the effects of panics last? Are panics shocks to the economy that get rapidly undone? Does output quickly revert back to trend? Or do panics disrupt the normal dynamics of output in ways that persist over time? There appears to be a growing consensus in the literature that banking crises can have long-term effects on output. Several recent studies - primarily confined to banking crises over the past half-century - have arrived at this conclusion. Using a panel data set for a large number of countries in the post-1960 period, Cerra and Saxena (2008) find that following financial crises, output does not, on average, revert back to its pre-crisis trend. In an analysis of 88 banking crises since 1970, The IMF's October 2009 World Economic Outlook concludes that output typically does not recover to its pre-crisis trend over the medium term - that is, within the first seven years after the crisis. In a study of 40 banking crises since 1980, Ceccheti, Kohler, and Upper (2009) find that many banking crises have lasting effects on output and that trend reversion —-when it occurs - tends to be a slow process. ${ }^{66}$

Do similar patterns hold for the banking panics of the pre-Great Depression era? The impulse response functions in figure 2 provide some insight into this question. The impacts on output in year 1 are large. But rather than weaken in subsequent years, the impacts hover at roughly the same level they did in year 1 - there is no reversion back to zero, suggesting that the effects of panics persist over time. ${ }^{67}$ The relatively constant level of the impact in subsequent years indicates that there may be a persistent level effect associated with panics. Even after output growth resumes, in other words, the level of output at any point in time may be lower than where it would have been had the panic never occurred.

To further investigate whether the banking panics of the pre-Great Depression era might have had long-term effects on trend output growth, I estimate a trend regression for each major banking panic. The regression takes the following form:

$$
\ln y_{t}=\alpha_{0}+\alpha_{1} D_{t}+\beta_{0} t+\beta_{1} D_{t} t+\varepsilon_{t},
$$

where $y_{t}$ is the Davis Index of Industrial Production in year $t$ and $D_{t}$ is a dummy variable that equals 1 if year $t$ is in the post-panic period and 0 if year $t$ is in the pre-panic period. I include the dummy variable to identify changes in trend following the panic. Since the Davis Index is available at an annual frequency and since I want to come as close as possible to separating periods by banking panics, I implement a

\footnotetext{
${ }^{66}$ Specifically, Ceccheti and Kohler (2009) find that the behavior of output varies widely following financial crises. In some instances, both the level of output and the trend rate of output growth decline following the crisis. In others, the level of output declines following the crisis, but trend output growth resumes its pre-crisis growth rate. In some cases, trend reversion occurs. However, in these latter cases, trend reversion tends to take a substantial number of years.

${ }^{67}$ Extending the model to include more lags finds that the estimated impacts are still below zero ten years out in all three specifications. However, the standard errors grow considerably over time, making the impacts in later years less precisely estimated.
} 
specific criterion for panic years. If the panic broke out in the first half of the year, then I include that year in the post-panic period. If the panic broke out in the second half of the year, then I include that year in the pre-panic period. For uniformity across panics, I restrict each pre-panic period to the fifteen years prior to the panic. To avoid contaminating the behavior of output following the panic with the behavior of output following a subsequent panic, each post panic period ends before the next major banking panic. Because there were three major banking panics during the 1830's-1833, 1837, and 1839, I begin my analysis in 1840, rather than try to estimate shifts in trend between the panics of 1833 and 1837, which only spans four years, and between the panics of 1837 and 1839, which only spans two years. Thus, I run four separate regressions, corresponding to each of the four major banking panics of the post-Jacksonian period: $1857,1873,1893$, and $1907 .^{68}$

Table 15 presents the results. The estimates of $\alpha_{1}$ and $\beta_{1}$ represent level and trend breaks at the beginning of the post-panic period. Figure 5 presents these estimates with $95 \%$ confidence intervals. The estimates of $\alpha_{1}$ are negative, large, and statistically significant across all four panics, indicating that there is a substantial decline in the level of output at the beginning of the post-panic period. By contrast, the estimates of $\beta_{1}$ differ across the four panics. For two panics - the panics of 1857 and 1873, the estimates of $\beta_{1}$ are -0.028 and -0.031 respectively, indicating that trend output growth declines following these panics. Trend effects are associated with these two panics - that is, output grows at a slower trend rate following these panics. For the panic of 1893 , the estimate of $\beta_{1}$ is statistically indistinguishable from zero, suggesting that trend output resumes its pre-panic growth rate. However, because there is a large initial decline in the level of output following the panic, a level effect is associated with this panic - that is, the level of output is permanently below where it would have been had output continued to follow its pre-panic trend. For the panic of 1873 , the estimate of $\beta_{1}$ is 0.017 , indicating that trend output growth increases following the panic and that output eventually crosses its pre-panic trend path. ${ }^{69}$

Figure 6 presents a graphical representation of these breaks in trend. It contains four graphs, with each graph corresponding to a different banking panic. Each graph plots the log of the Davis Index of Industrial Production on the vertical axis and year on the horizontal axis. Pre-panic and post-panic trends - based on the above regressions - are contained in each graph. To show where output would have been had it continued to follow its pre-panic trend, I project each pre-panic trend line out into the subsequent period. The solid lines represent actual trends whereas the dashed lines represent projected trends. Following the panics of 1857, 1893, and 1907, the actual trend line falls below the projected trend line. In these three instances, output does not revert back to its pre-panic trend. For the panic of 1893, the projected and actual trends are parallel, suggesting that a level effect is associated with this panic. For the panics of 1857 and 1907 , the actual trend is significantly flatter than the projected trend, indicating that trend output growth declines following these panics. In the remaining projection-the one

\footnotetext{
${ }^{68}$ This approach is similar to the framework used by Cecchetti, Kohler, and Upper (2009) to identify breaks in trend output growth following financial crises in the post-1980 period.

${ }^{69}$ What explains these differences in the behavior of output across these four panics? The $19^{\text {th }}$ century was a period of dramatic economic transformation. Technological advances or institutional changes over this period could have had an impact on trend output growth as well. Thus, some of the variation in the behavior of output across these panics might reflect these other forces.
} 
corresponding to the 1873 panic episode, the actual trend line crosses the projected trend line, indicating that output reverts back to its pre-panic trend.

These results for the pre-Great Depression era are consistent with the growing consensus in the literature that banking crises can have lasting effects on output. Several papers have recently attempted to explain why banking crises might have persistent effects on output. Cecchetti, Kohler, and Upper (2009) speculate that increased risk aversion in the aftermath of banking crises could lower capital accumulation in the long run and that sharp increases in the size of government debt - the result of fiscal stimulus measures and bank stabilization policies - could lead to crowding out effects that dampen economic growth for years. $^{70}$ Ramirez (2008) presents evidence that before the advent of deposit insurance, banking panics reduced trust in the banking system and induced depositors to keep their money out of the banking system, thereby impairing an economy's ability to conduct effective financial intermediation services over time. The IMF's October 2009 World Economic Outlook speculates that banking panics are associated with declines in potential output - the level of output consistent with stable inflation and full employment. In a recent empirical study, Furceri and Mourougane (2009) find some evidence of this: according to their results, financial crises reduce potential output by $2 \%$ on average.

What do these results predict for the path of output following the 2007-2009 banking crisis? While it is impossible to precisely predict how output will behave in the aftermath of this crisis, the results of these studies and the findings of this paper suggest that reversion to the pre-crisis trend is far from certain. Moreover, it is plausible that forces beyond the scope of this paper-policies designed to stimulate economies, avoid deflation and stabilize banking systems - might have a significant impact on the trajectory of output following the current crisis.

\section{Part V. Conclusions}

There are two major problems in identifying the real output effects of financial panics of the preGreat Depression era. First, it is not clear when panics occurred because prior panic series differ in their identification of panics. Second, even if the timing of when panics occurred is consistent with panics having real output effects, establishing the direction of causality is tricky: are panics causing downturns or are downturns causing panics?

This study sequentially addresses these two problems. It accomplishes this (1) by developing a new series on banking panics for the 1825-1929 period-one that rectifies many of the problems of earlier series - and (2) by studying the output effects of major banking panics that the reports of contemporary observers suggest were the result of idiosyncratic disturbances, as opposed to declining output conditions.

In the process, I discover some major misconceptions in the history of American financial panics. First, prior panic series presented flawed lists of when panics occurred. Several series lumped together different types of financial disturbances-banking panics, stock market disturbances, spikes in interest rates - under the common heading of panic. Some series omitted important panic episodes. In a few

\footnotetext{
${ }^{70}$ The latter possibility—crowding out effects brought on by sudden increases in the size of government debt—can be ruled out for the panics of the pre-Great Depression era since government intervention was minimal surrounding these panics.
} 
series, foreign panics were listed as domestic ones. These inconsistencies are the result of methodological flaws in the development of earlier series. Many panic series did not explicitly define a panic and most series did not adopt a consistent rule to identify panics.

Second, contrary to the conventional wisdom, there is no evidence of a decline in the frequency of financial panics during the first fifteen years of the existence of the Federal Reserve. The orthodox view in the literature - that the frequency of panics was high before 1914 and that the frequency dramatically decreased between 1914 and 1929-was based on an unreliable panic series.

Third, prior studies on the causes and effects of panics based their conclusions on inconsistent panic series. While my findings support the general conclusions of Miron (1986) that major financial panicsin particular, major banking panics-were more likely to occur during particular seasons prior to the founding of the Federal Reserve, Miron employed an unreliable panic series - the Kemmerer series - to document the incidence of panics before 1914. Moreover, DeLong and Summers (1986), in an influential work on historical changes in business cycle variability, concluded that (1) the real output effects of panics are smaller than generally realized and (2) there is little support for the hypothesis that panics were a substantial source of economic instability prior to WWII. However, my results show the exact opposite: major banking panics have large and significant real output effects and they were a significant source of economic instability before WWII. DeLong and Summers missed the link between panics and downturns because they relied on a flawed panic series.

As for the results of my empirical test, I find that major banking panics have large effects. My results indicate that banking panics have strongly significant effects on output. According to the baseline regressions, output growth declines by approximately 9 to 13 percentage points in the year following a major banking panic. In addition, using monthly data on real economic activity, I show that panics have immediate effects on output, with large declines beginning in the month in which the panic breaks out. These results are robust to a variety of specifications.

My results also indicate that banking panics have significant effects on inflation and the price level. According to the empirical findings, banking panics cause declines in the price level of 11 to 13 percent within one year, depending on the specification. The decline is most rapid in the immediate months following the panic, but continues over the course of a year.

These findings shed important insights into the causes of the Great Depression. Banking panics cause large declines in output, suggesting that the banking panics of the Great Depression can account for a significant portion of the output losses occurring between 1930 and 1933. These results are consistent with the view of Friedman and Schwartz (1963) that a wave of banking panics converted a normal downturn into a severe depression. They also support the work of Bernanke and James (1991) who find that countries with banking panics had more severe downturns between 1929 and 1933 than countries without banking panics.

Moreover, these results have several implications for today's current banking crisis. First, banking panics produce deflationary shocks, making the avoidance of deflation a well-justified goal of policy today. Policymakers have recently expressed concerns about the potential deflationary consequences of the 2007-2009 banking crisis. Recently released minutes of the Federal Open Market Committee 
meetings reveal that Fed officials are closely monitoring for any signs of deflation, with many officials already seeing "significant risks that inflation could decline and persist for a time at uncomfortably low levels." 71 That the banking panics of the pre-Federal Reserve era were followed by large declines in prices legitimizes these concerns.

Second, if historical trends continue, the current downturn is likely to be longer and substantially more severe than the typical postwar recession in the United States. Output recovery-defined as the length of time it takes output to recover back to its pre-trend peak-is likely to be substantially longer than the typical output recovery following other postwar recessions. In the post Civil War era, downturns with major banking panics were slightly longer and substantially more severe than downturns without them on average, and output recoveries for downturns with major banking panics were two-to-three times the length of output recoveries for downturns without them.

Third, the effects of major banking panics can persist over time. This is important both from the perspective of adopting policies to mitigate output losses and from the perspective of forecasting what might happen to output when the economy begins to turn around. Output does not necessarily revert back to trend following a major banking panic. Indeed, output did not revert back to its pre-panic trend following three of the four major banking panics between 1857 and 1914. These findings underscore the stakes of today's current banking crisis and should raise warnings that the U.S. economy could end up on a lower output trajectory or that it could take many years for output to catch up to its pre-crisis trend. It is highly plausible that forces beyond the scope of this study-policies designed to stimulate economies, avoid deflation and stabilize banking systems - could have a significant impact on the path of output in the aftermath of this banking crisis.

\footnotetext{
${ }^{71}$ Minutes of the Federal Open Market Committee, December 15-16, 2008.
} 


\section{References}

Bernanke, Ben S. and James, Harold. 1991. "The Gold Standard, Deflation, and Financial Crisis in the Great Depression: An International Comparison," in Financial Markets and Financial Crises. Ed.: R. Glenn Hubbard. Chicago: U. of Chicago Press, pp. 33-68.

Board of Governors of the Federal Reserve System. Minutes of the Federal Open Market Committee, December 2008.

Bordo, Michael D. 1989. "The Contribution of A Monetary History of the United States, 1867-1960 to Monetary History." In Money, History, and International Finance: Essays in Honor of Anna J. Schwartz, edited by Michael D. Bordo, Chicago: University of Chicago Press.

Bordo, Michael D. and Barry Eichengreen. 1999. "Is Our Current International Economic Environment Unusually Crisis Prone?" manuscript, Department of Economics, University of California, Berkeley, August.

Bordo, Michael D., Barry Eichengreen, Daniela Klingebiel, and Maria Soledad Martinez-Peria. 2001. "Is the Crisis Problem Growing More Severe?" Economic Policy 16 (Aug): 51-82.

Bordo, Michael D. and David C. Wheelock. 1988. "Price Stability and Financial Stability: The Historical Record," Fed of St. Louis Review, Sep/Oct., 41-62

Bordo, Michael, Charles W. Calomiris, and Gary Gorton. 1991. "The Origins of Banking Panics: Models, Facts, and Bank Regulation.” In Financial Markets and Financial Crises, edited by R. Glenn Hubbard, Chicago: University of Chicago Press, pp. 109-74.

Calomiris, Charles W. and R. Glenn Hubbard. 1989. "Price Flexibility, Credit Availability, and Economic Fluctuations: Evidence from the United States, 1894-1909.” Quarterly Journal of Economics 104 (August): 429-452

Calomiris, Charles, and Larry Schweikart. 1991. "The Panic of 1857: Origins, Transmission, and Containment." Journal of Economic History (December): 807-834.

Catterall, Ralph. 1903. The Second Bank of the United States. Chicago: University of Chicago Press.

Cecchetti, Stephen G., Marion Kohler, and Christian Upper. 2009. "Financial Crises and Economic Activity.” NBER Working Paper No. 15379.

Cerra, Valerie and Sweta Saxena. 2008. "Growth Dynamics: The Myth of Economic Recovery." American Economic Review (March): 439-457.

Cole, Arthur H. 1930. "Statistical Background of the Crisis of 1857." The Review of Economic Statistics 12 (November): 170-180.

Cole, Arthur H. 1957. "Conspectus for a History of Economic and Business Literature." Journal of Economic History 17 (September): 333-388.

Commercial and Financial Chronicle, 1865-1933. New York

Comptroller of the Currency. Annual Report. Washington: Government Printing Office, various years.

Conant, Charles. 1915. A History of Modern Banks of Issue, $5^{\text {th }}$ edition. New York: G.D. Putnam's Sons.

Davis, Joseph H. 2004. “An Annual Index of U.S. Industrial Production, 1790-1915.” Quarterly Journal of Economics 119 (November): 1177-1215. 
Davis, Joseph H. 2006. “An Improved Annual Chronology of U.S. Business Cycles since the 1790s.” The Journal of Economic History 66 (March): 103-121.

DeLong, Bradford J. and Lawrence H. Summers. 1986. "The Changing Cyclical Variability of Economic Activity in the United States." in R. J. Gordon, ed., The American Business Cycle: Continuity and Change. Chicago: Chicago University Press, 1986. pp. 679-719

Engerman, Stanley L. 1970. "A Note on the Economic Consequences of the Second Bank of the United States." 78 (July-August): 725-728.

Fels, Rendigs. 1959. American Business Cycles, 1865-1897. Chapell Hill, N.C.,

Friedman, Milton and Schwartz, Anna J. 1963. A Monetary History of the United States, 1867-1960. Princeton: Princeton University Press.

Furceri, David and Annabelle Mourougane. 2009. "The Effects of Financial Crises on Potential Output: New Empirical Evidence from OECD Countries.” OECD Economics Department Working Paper No. 699.

Glasner, David. 1997. “Crisis of 1873.” In Business Cycles and Depressions, edited by D. Glasner, New York: Garland Publishing, pp. 132-134.

Goodhart, C.A.E. 1997. “Crisis of 1907.” In Business Cycles and Depressions, edited by D. Glasner, New York: Garland Publishing, pp. 134-135.

Gordon, Robert J. 1986. The American Business Cycle. Chicago: University of Chicago Press.

Gorton, Gary. 1988. "Banking Panics and Business Cycles.” Oxford Economic Papers 40: 751-781.

Grossman, Richard S. 1993. "The Macroeconomic Consequences of Bank Failures under the National Banking System.” Explorations in Economic History. 30: 294-320.

International Monetary Fund. October 2009. World Economic Outlook.

International Monetary Fund. World Economic Outlook Database.

Kelly, Morgan and Cormac O'Grada. 2000. "Market Contagion: Evidence from the Panics of 1854 and 1857." American Economic Review 90 (5): 1110-1124.

Kemmerer, E.W., Seasonal Variations in the Relative Demand for Money and Capital in the United States, National Monetary Commission, S.Doc.588, $61^{\text {st }}$ Cong., $2 \mathrm{~d}$ session, 1910

Literary Digest, 1890-1938. New York.

Long, Clarence D. 1940. Building Cycles and the Theory of Investment, Princeton: Princeton University Press.

Meerman, Jacob P. 1963. "The Climax of the Bank War: Biddle's Contraction, 1833-34." The Journal of Political Economy. 71 (August): 378-388.

Meltzer, Allan H. 2003. A History of the Federal Reserve, Vol. 1 Chicago, University of Chicago Press Merchants' Magazine and Commercial Review, 1839-1879. New York.

Miron, Jeffrey A. 1986. "Financial Panics, the Seasonality of the Nominal Interest Rate, and the Founding of the Fed." American Economic Review 76 (March): 125-140

Miron, Jeffrey A. 1996. The Economics of Seasonal Cycles. MIT Press, Cambridge

Miron, Jeffrey A. and Christina D. Romer. 1990. “A New Monthly Index of Industrial Production." The Journal of Economic History. 50 (June): 321-337. 
Mitchell, Wesley C. 1913. Business Cycles and Their Causes. Berkeley, Calif.: University of California Press.

New York Commercial Advertiser, 1790-1889. New York.

Niles Weekly Register, 1811-1849. Baltimore.

O'Grada, Cormac and Eugene N. White. 2003. "The Panics of 1854 and 1857: A View from the Emigrant Industrial Savings Bank.” The Journal of Economic History 63 (March): 213-240.

President and Fellows of Harvard College. 1939. "On the Hundredth Anniversary of the Commercial \& Financial Chronicle.” Bulletin of the Business Historical Society. 13 (November): 67-72.

Ramey, Valerie A. 2008. "Identifying Government Spending Shocks: It's All in the Timing." Unpublished manuscript, University of California, San Diego (June).

Ramey, Valerie A. and Matthew D. Shapiro. 1998. "Costly Capital Reallocation and the Effects of Government Spending.” Carnegie-Rochester Conference Series on Public Policy 48 (June): 145194.

Ramirez, CD. 2009. 'Bank Fragility, 'Money Under the Mattress,' and Long-Run Growth: U.S. Evidence from the 'Perfect' Panic of 1893, mimeo.

Reinhart, Carmen M., and Kenneth S. Rogoff. 2008a. "Is the 2007 U.S. Subprime Crisis So Different? An International Historical Comparison." American Economic Review Vol. 98 No. 2: 339-344.

Reinhart, Carmen M. and Kenneth S. Rogoff. 2008b. "This Time is Different: A Panoramic View of Eight Centuries of Financial Crises.” NBER Working Paper Series.

Reinhart, Carmen M. and Kenneth S. Rogoff. 2008c. "Banking Crises: An Equal Opportunity Menace." NBER Working Paper Series.

Romer, Christina D. 1990. "The Great Crash and the Onset of the Great Depression." Quarterly Journal of Economics 105 (August): 597-624.

Romer, Christina D. 1999. "Changes in Business Cycles: Evidence and Explanations." Journal of Economic Perspectives 13 (Spring): 23-44

Romer, Christina D., and David H. Romer. 1989. "Does Monetary Policy Matter? A New Test in the Spirit of Friedman and Schwartz." NBER Macroeconomics Annual 4: 121-170.

Romer, Christina D., and David H. Romer. 2004. "A New Measure of Monetary Shocks: Derivation and Implications." American Economic Review 94 (September): 1055-1084.

Romer, Christina D., and David H. Romer. 2008. "The Macroeconomic Effects of Tax Changes: Estimates Based on a New Measure of Fiscal Shocks." Unpublished Manuscript, University of California, Berkeley (November).

Rousseau, Peter L. 2002. "Jacksonian Monetary Policy, Specie Flows, and the Panic of 1837." The Journal of Economic History 62 (September): 457-488.

Sprague, O.M.W. 1910. History of Crises Under the National Banking System, National Monetary Commission, S.Doc. 538, $61^{\text {st }}$ Cong., $2 \mathrm{~d}$ session

Schwartz, Anna J. 1986. "Real and Pseudo-Financial Crises," in F. Capie and G.E. Wood, eds., Financial Crises and the World Banking System. London: Macmillan, pp. 11-31 
Schwartz, Anna J. "Financial Stability and the Federal Safety Net," in William S. Haraf and Rose Marie Kushneider, eds., Restructuring Banking and Financial Services in America, American Enterprise Institute, 1988, pp. 34-62.

Swanson, William Walker. 1908a. "The Crisis of 1860 and the First Issue of Clearing-House Certificates: I.” Journal of Political Economy. 16 (February): 65-75.

Swanson, William Walker. 1908a. "The Crisis of 1860 and the First Issue of Clearing-House Certificates: II." Journal of Political Economy. 16 (April): 212-226.

Temin, Peter. 1968. "The Economic Consequences of the Bank War." The Journal of Political Economy. 76 (March-April): 257-274.

Temin, Peter. 1969. The Jacksonian Economy. Norton New York.

Temin, Peter. 1976. Did Monetary Forces Cause the Great Depression? Norton New York.

Thorp, Willard L. 1926. Business Annals. NBER, New York.

Vickers, Raymond. 1994. Panic in Paradise: Florida's Banking Crash of 1926. University of Alabama.

White, Eugene N. 1984. "A Reinterpretation of the Banking Crisis of 1930," Journal of Economic History 44, 119-138.

Wicker, Elmus. 2000. Banking Panics of the Gilded Age. New York: Cambridge University Press 
Table 1. Eight Panic Series, 1825-2007

\begin{tabular}{|c|c|c|c|c|c|c|c|c|}
\hline Bordo-Wheelock & Thorp & Reinhart-Rogoff: Table A3 & \begin{tabular}{|l|l|} 
Reinhart--Rogoff: Table A5 \\
\end{tabular} & Gorton & Sprague & Wicker & Kemmerer & DeLong-Summers \\
\hline Banking Panic & Panic & Banking Crisis & Banking Crisis & Banking Panic & Crisis & Banking Panic & Panic & Panic \\
\hline $1790-1933$ & $1790-1925$ & $1800-2007$ & $1800-2007$ & 1863-1914 & $1864-1910$ & $1864-1914$ & $1873-1908$ & 1890-1913 \\
\hline 1825 & 1825 & 1825 & Jan 1825 & & & & & \\
\hline \multirow[t]{2}{*}{1833} & 1833 & & & & & & & \\
\hline & & 1836 & & & & & & \\
\hline 1837 & 1837 & & March $1837-1838$ & & & & & \\
\hline \multirow[t]{3}{*}{1839} & 1839 & & & & & & & \\
\hline & & & March 1841 & & & & & \\
\hline & 1847 & & & & & & & \\
\hline \multirow[t]{3}{*}{1857} & 1857 & 1857 & Aug 1857 & & & & & \\
\hline & & & Dec 1861 & & & & & \\
\hline & & & April 1864 & & & & & \\
\hline \multirow[t]{2}{*}{1873} & 1873 & 1873 & Sept 1873 & Sept 1873 & 1873 (Crisis) & Sept 1873 (Panic) & Sept 1873 (Major) & \\
\hline & & & & & & & April 1876 (Minor) & \\
\hline \multirow[t]{4}{*}{1878 (financial distress) } & & & & & & & & \\
\hline & & & & & & & Nov 1879 (Minor) & \\
\hline & & & & & & & May-June 1880 (Minor) & \\
\hline & & & & & & & March-April 1882 (Minor) & \\
\hline \multirow[t]{3}{*}{1884 (financial distress) } & & 1884 & May 1884 & June 1884 & 1884 (Panic) & May 1884 (Incipient Panic) & May 1884 (Major) & \\
\hline & & & & & & & June 1887 (Minor) & \\
\hline & & & & & & & March-Apil 1888 (Minor) & \\
\hline \multirow[t]{2}{*}{1890 (financial distress) } & & 1890 & & Nov 1890 & 1890 (Financial Stringency) & Nov 1890 (Incipient Panic) & Nov 1890 (Major) & $1890: 4$ \\
\hline & & & & & & & Feb 1893 (Minor) & \\
\hline \multirow[t]{20}{*}{1893} & 1893 & & May 1893 & May 1893 & 1893 (Crisis) & Jun-Aug 1893 (Panic) & May - Aug 1893 (Major) & $1893: 2$ and $1893: 3$ \\
\hline & & & & & & & Sept-Dec 1895 (Minor) & \\
\hline & & & & & & & & $1896: 1$ \\
\hline & & & & Oct 1896 & & & June-July 1896 (Minor) & $1896: 3$ \\
\hline & & & & & & & Dec 1896 (Minor) & \\
\hline & & & & & & & March 1898 (Minor) & \\
\hline & & & & & & & & $1898: 2$ \\
\hline & & & & & & & Sept 1899 (Minor) & \\
\hline & & & & & & & Dec 1899 (Major) & 1899:4 \\
\hline & & & & & & & May 1901 (Major) & $1901: 2$ \\
\hline & & & & & & & July 1901 (Minor) & \\
\hline & & & & & & & Sept 1901 (Minor) & \\
\hline & & & & & & & Sept-Nov 1902 (Minor) & \\
\hline & & & & & & & March - Aug 1903 (Major) & 1903:2 \\
\hline & & & & & & & Dec 1904 (Minor) & \\
\hline & & & & & & & April 1905 (Minor) & \\
\hline & & & & & & & & $1905: 4$ \\
\hline & & & & & & & April-May 1906 (Minor) & \\
\hline & & & & & & & Dec 1906 (Minor) & \\
\hline & & & March 1907 & & & & March 1907 (Minor) & \\
\hline \multirow[t]{4}{*}{1907} & 1907 & 1907 & & 0ct-07 & 1907 (Crisis) & Oct 1907 (Panic) & Oct 1907 (Major) & $1907: 4$ \\
\hline & & & & & & & Sept 1908 (Minor) & \\
\hline & & & & & & & & 1909:4 \\
\hline & & 1914 & Jul-14 & Aug-14 & & & & \\
\hline \multicolumn{9}{|l|}{ 1920s (financial distress) } \\
\hline \multirow{4}{*}{\begin{tabular}{r|}
$1929-1933$ \\
1980 s (financial distress) \\
\end{tabular}} & & 1929 & 1929-1933 & & & & & \\
\hline & & & & & & & & \\
\hline & & 1984 & 1984-1991 & & & & & \\
\hline & & 2007 & & & & & & \\
\hline
\end{tabular}


Table 2. New Series on Banking Panics, 1825-1929

\begin{tabular}{|c|c|}
\hline Major Banking Panic & Minor Banking Panic \\
\hline \multicolumn{2}{|l|}{ Nov 1833 - Apr 1834} \\
\hline \multicolumn{2}{|l|}{ Mar - May 1837} \\
\hline \multicolumn{2}{|l|}{ Oct 1839} \\
\hline & Jan - April $1841(\mathrm{PA}, \mathrm{DE}, \mathrm{MD}, \mathrm{NC}, \mathrm{VA}, \mathrm{IL})$ \\
\hline & Mar $1842(\mathrm{PA})$ \\
\hline & May - Jun 1842 (New Orleans) \\
\hline & Oct $1851(\mathrm{NY}, \mathrm{NJ}, \mathrm{MD})$ \\
\hline & Sep 1854 - Feb $1855\left(\mathrm{OH}_{1}\right.$ IN, MI, WI, IA, MO, NY, CA) \\
\hline \multicolumn{2}{|l|}{ Aug - Oct 1857} \\
\hline & Nov 1860 (suspension of specie payments by banks in the South) \\
\hline & Dec 1861 (generalized suspension of specie payments) \\
\hline \multicolumn{2}{|l|}{ Sep 1873} \\
\hline & May $1884(\mathrm{NYC}, \mathrm{PA}, \mathrm{NJ})$ \\
\hline & Nov 1890 (New York City) \\
\hline \multicolumn{2}{|l|}{ May - Aug 1893} \\
\hline & Dec $1896(\mathrm{IL}, \mathrm{MN}, \mathrm{WI})$ \\
\hline & Dec 1899 (Boston and New York City) \\
\hline & Jun - Jul 1901 (New York: Buffalo and NYC) \\
\hline & Oct $1903(\mathrm{PA}, \mathrm{MD})$ \\
\hline & Dec 1905 (Chicago) \\
\hline \multicolumn{2}{|l|}{ Oct - Nov 1907} \\
\hline & Jan 1908 (New York City) \\
\hline & Aug - Sep 1920 (Boston) \\
\hline & Nov 1920 - Feb 1921 (North Dakota) \\
\hline & Jul $1926(F L, G A)$ \\
\hline & Mar $1927(\mathrm{FL})$ \\
\hline & Jul - Aug 1929 (FL) \\
\hline
\end{tabular}




\section{Table 3. Comparison of Eight Earlier Panic Series with New Series on Banking Panics}

Entries with a Strike Through Them Denote Episodes Not Listed in New Series on Banking Panics. Those episodes do not contain banking panics.

\begin{tabular}{|c|c|c|c|c|c|c|c|c|c|c|}
\hline Bordo-Wheelock & Thorp & Reinhart-Rogoff: $A 3$ R & Reinhart--Rogoff: A5 & Gorton & Sprague & Wicker & Kemmerer & DeLong-Summers & New Series (Major) & New Series (Minor) \\
\hline $1790-1933$ & $1790-1925$ & \begin{tabular}{|l|l|}
$1800-2007$ \\
\end{tabular} & & 1863-1914 & $1864-1910$ & 1864-1914 & 1873-1908 & $1890-1913$ & $1825-1929$ & $1825-1929$ \\
\hline 1825 & 1825 & 1825 & $\tan 1825$ & & & & & & & \\
\hline \multirow[t]{2}{*}{1833} & 1833 & & & & & & & & Nov 1833 - Apr 1834 & \\
\hline & & 1836 & & & & & & & & \\
\hline 1837 & 1837 & & March $1837-1838$ & & & & & & Mar - May 1837 & \\
\hline \multirow[t]{7}{*}{1839} & 1839 & & & & & & & & Oct 1839 & \\
\hline & & & March 1841 & & & & & & & Jan - April 1841 \\
\hline & & & & & & & & & & Mar 1842 \\
\hline & & & & & & & & & & May - Jun 1842 \\
\hline & 1847 & & & & & & & & & \\
\hline & & & & & & & & & & October 1851 \\
\hline & & & & & & & & & & Sep 1854 - Apr 1855 \\
\hline \multirow[t]{4}{*}{1857} & 1857 & 1857 & Aug 1857 & & & & & & Aug - Oct 1857 & \\
\hline & & & & & & & & & & Nov 1860 \\
\hline & & & Dec 1861 & & & & & & & Dec 1861 \\
\hline & & & April1864 & & & & & & & \\
\hline \multirow[t]{2}{*}{1873} & 1873 & 1873 & Sept 1873 & Sept 1873 & 1873 (Crisis) & Sept 1873 (Panic) & Sept 1873 (Major) & & Sep 1873 & \\
\hline & & & & & & & April 1876 (Minor) & & & \\
\hline \multicolumn{11}{|l|}{1878 (financial distress) } \\
\hline & & & & & & & Hov 1879 (Miner) & & & \\
\hline & & & & & & & May-June 1880 (Miner) & & & \\
\hline & & & & & & & March-Aprill 1882 (Minor) & & & \\
\hline \multirow[t]{3}{*}{1884 (financial distress) } & & 1884 & May 1884 & June 1884 & 1884 (Panic) & May 1884 (Incipient Panic) & May 1884 (Major) & & & May 1884 \\
\hline & & & & & & & June 1887 (Minor) & & & \\
\hline & & & & & & & March-Apill1888 (Minnor) & & & \\
\hline \multirow[t]{2}{*}{1890 (financial distress) } & & 1890 & & Nov 1890 & 1890 (Stringency) & Nov 1890 (Incipient Panic) & Nov 1890 (Major) & 1890:4 & & Nov 1890 \\
\hline & & & & & & & Feb 1893 (Minor) & & & \\
\hline \multirow[t]{21}{*}{1893} & 1893 & & May 1893 & May 1893 & 1893 (Crisis) & ) June-August 1893 (Panic) & May - Aug 1893 (Major) & $1893: 2$ and $1893: 3$ & May-Aug 1893 & \\
\hline & & & & & & & Sept-Dec 1895 (Minor) & & & \\
\hline & & & & & & & & 189641 & & \\
\hline & & & & $\theta$ Oct 1896 & & & June-July 1896 (Minof) & 1896:3 & & \\
\hline & & & & & & & Dec 1896 (Minor) & & & Dec 1896 \\
\hline & & & & & & & March 1898 (Minnor) & & & \\
\hline & & & & & & & & $1898: 2$ & & \\
\hline & & & & & & & Sept 1899 (Minor) & & & \\
\hline & & & & & & & Dec 1899 (Major) & 1899:4 & & Dec 1899 \\
\hline & & & & & & & May 1901 (Majof) & 1901:2 & & \\
\hline & & & & & & & July 1901 (Minor) & 1901:2 (same as above) & & Jun-Jul 1901 \\
\hline & & & & & & & Sept 1901 (Minet) & & & \\
\hline & & & & & & & Sept-Nov 1902 (Minor) & & & \\
\hline & & & & & & & March-Aug 1903 (Major) & 1903:2 & & \\
\hline & & & & & & & & & & Oct 1903 \\
\hline & & & & & & & Dec 1904 (Minor) & & & \\
\hline & & & & & & & April1 1905 (Minor) & & & \\
\hline & & & & & & & & 1905:4 & & Dec 1905 \\
\hline & & & & & & & April-May 1906 (Minor) & & & \\
\hline & & & & & & & Dec 1906 (Minof) & & & \\
\hline & & & March 1907 & & & & March 1907 (Minor) & & & \\
\hline \multirow[t]{10}{*}{1907} & 1907 & 1907 & & Oct-07 & 1907 (Crisis) & Oct 1907 (Panic) & Oct 1907 (Major) & $1907: 4$ & Oct - Nov 1907 & \\
\hline & & & & & & & & & & Jan 1908 \\
\hline & & & & & & & Sept 1908 (Minor) & & & \\
\hline & & & & & & & & $1909 \div 4$ & & \\
\hline & & 1914 & Jut-14 & Aug-14 & & & & & & \\
\hline & & & & & & & & & & Aug - Sep 1920 \\
\hline & & & & & & & & & & Nov 1920 - Feb 1921 \\
\hline & & & & & & & & & & Jul 1926 \\
\hline & & & & & & & & & & Mar 1927 \\
\hline & & & & & & & & & & Jul-Aug 1929 \\
\hline
\end{tabular}


Table 4. Frequency of Banking Panics

Banking Panics
\begin{tabular}{|l|l|l|} 
Average Rate & Post-Fed (1914 - 1929) \\
Major & $\begin{array}{l}\text { one every 12.9 years } \\
\text { (median \# years b/w major bank panics = 16) }\end{array}$ & $\begin{array}{l}\text { no major banking panics between 1914 and 1929 } \\
\text { (next one occurs in 1930, 16 years after 1914) }\end{array}$ \\
\hline Minor & one every 6 years & one every 3.5 years \\
\hline
\end{tabular}

Table 5. Seasonality of Banking Panics

\begin{tabular}{|l|r|r|}
\hline Distribution of Panics by Starting Months \\
\hline \hline \multirow{3}{*}{ Spring } & 1 & \\
\cline { 2 - 3 } March & 1 & 1 \\
April & 0 & 0 \\
May & & 2 \\
Summer & 0 & \\
June & 0 & 1 \\
July & 1 & 0 \\
August & & 0 \\
Fall & 1 & \\
September & 2 & 1 \\
October & 1 & 2 \\
November & & 2 \\
Winter & 0 & 4 \\
December & 0 & 2 \\
January & 0 & 0 \\
February & & \\
& & \\
\hline Percentage Spring \& Fall & 14.3 & 47.7 \\
\hline Percentage Summer \& Winter & & \\
\hline
\end{tabular}

Table 6. Correlation of Major Banking Panics and Downturns

\begin{tabular}{|r|r|}
\hline Panic & Percent Change in Davis Index \\
\hline 1833 & $-4.5 \%$ from 1833 to 1834 \\
\hline 1837 & $-1.4 \%$ from 1837 to 1838 \\
\hline 1839 & $-4.7 \%$ from 1839 to 1840 \\
\hline 1857 & $-8.0 \%$ from 1856 to 1858 \\
\hline 1873 & $-6.0 \%$ from 1873 to 1875 \\
\hline 1893 & $-15.3 \%$ from 1892 to 1894 \\
\hline 1907 & $-15.6 \%$ from 1907 to 1909 \\
\hline
\end{tabular}


Table 7. Classification of Panics

\begin{tabular}{|r|r|r|}
\hline Panic & Dimension 1 & Dimension 2 \\
\hline 1833 & 3 & 3 \\
\hline 1837 & No Rank & No Rank \\
\hline 1839 & No Rank & No Rank \\
\hline 1857 & 3 & 3 \\
\hline 1873 & 3 & 3 \\
\hline 1893 & 3 & 1 \\
\hline 1907 & 2 & 1 \\
\hline
\end{tabular}


Table 8. The Impact of Banking Panics on Industrial Production

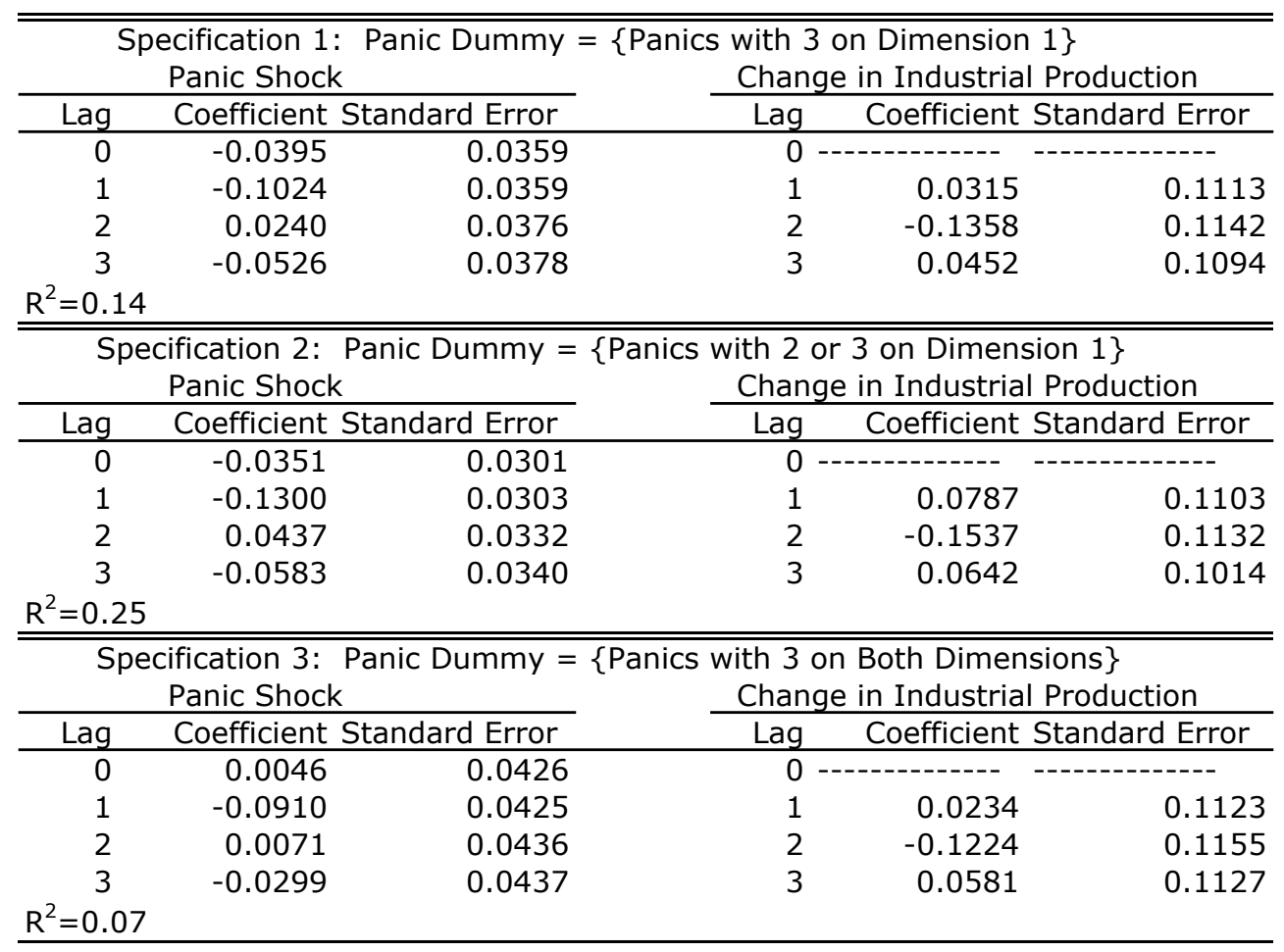


Table 9. Panic of 1893: Miron-Romer Index of Industrial Production (Seasonally Adjusted)

\begin{tabular}{|l|r|r|}
\hline Month & Index & Percent Change \\
\hline Nov-1892 & 60.1 & -0.67 \\
\hline Dec-1892 & 60.3 & 0.46 \\
\hline Jan-1893 & 60.2 & -0.24 \\
\hline Feb-1893 & 60.2 & 0.07 \\
\hline Mar-1893 & 61.2 & 1.70 \\
\hline Apr-1893 & 60.7 & -0.97 \\
\hline May-1893 & $\mathbf{5 9 . 4}$ & $\mathbf{- 2 . 0 1}$ \\
\hline Jun-1893 & $\mathbf{5 8 . 7}$ & $\mathbf{- 1 . 2 2}$ \\
\hline Jul-1893 & $\mathbf{5 6 . 3}$ & $\mathbf{- 4 . 1 3}$ \\
\hline Aug-1893 & $\mathbf{5 4 . 7}$ & $\mathbf{- 2 . 8 9}$ \\
\hline Sep-1893 & 54.8 & 0.17 \\
\hline Oct-1893 & 53.2 & -2.85 \\
\hline Nov-1893 & 52.2 & -1.89 \\
\hline Dec-1893 & 52.3 & 0.31 \\
\hline Jan-1894 & 51.3 & -1.96 \\
\hline Feb-1894 & 51.0 & -0.66 \\
\hline
\end{tabular}

Table 10. Panic of 1907: Miron-Romer Index of Industrial Production (Seasonally Adjusted)

\begin{tabular}{|r|r|r|}
\hline \multicolumn{1}{|l|}{ Month } & Index & Percent Change \\
\hline Apr-07 & 97.66 & 0.48 \\
\hline May-07 & 99.31 & 1.69 \\
\hline Jun-07 & 102.19 & 2.90 \\
\hline Jul-07 & 103.48 & 1.26 \\
\hline Aug-07 & 102.17 & -1.27 \\
\hline Sep-07 & 100.11 & -2.02 \\
\hline Oct-07 & 96.66 & -3.45 \\
\hline Nov-07 & $\mathbf{9 2 . 3 5}$ & -4.45 \\
\hline Dec-07 & 90.00 & -2.54 \\
\hline Jan-08 & 88.25 & -1.95 \\
\hline Feb-08 & 85.72 & -2.86 \\
\hline Mar-08 & 83.97 & -2.04 \\
\hline Apr-08 & 83.61 & -0.43 \\
\hline May-08 & 82.72 & -1.07 \\
\hline
\end{tabular}


Table 11. The Impact of Banking Panics on Construction

\begin{tabular}{|c|c|c|c|c|c|}
\hline \multicolumn{6}{|c|}{ Specification 1: Panic Dummy = \{Panics with 3 on Dimension 1$\}$} \\
\hline \multicolumn{3}{|c|}{ Banking Panic Shock } & \multicolumn{3}{|c|}{ Change in Index } \\
\hline Lag & \multicolumn{2}{|c|}{ Coefficient Standard Error } & Lag & \multicolumn{2}{|c|}{ Coefficient Standard Error } \\
\hline 0 & -0.2829 & 0.1682 & 0 & 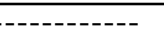 & ----- \\
\hline 1 & -0.3349 & 0.1684 & 1 & -0.6597 & 0.0458 \\
\hline 2 & -0.8491 & 0.1686 & 2 & -0.4175 & 0.0543 \\
\hline 3 & -0.4544 & 0.1729 & 3 & -0.4385 & 0.0568 \\
\hline 4 & -0.2235 & 0.1738 & 4 & -0.3517 & 0.0597 \\
\hline 5 & 0.0146 & 0.1737 & 5 & -0.3423 & 0.0609 \\
\hline 6 & -0.0713 & 0.1736 & 6 & -0.2727 & 0.0622 \\
\hline 7 & -0.2234 & 0.1735 & 7 & -0.1792 & 0.0631 \\
\hline 8 & 0.0484 & 0.1738 & 8 & -0.1978 & 0.0631 \\
\hline 9 & 0.0131 & 0.1727 & 9 & -0.2479 & 0.0636 \\
\hline 10 & -0.3459 & 0.1726 & 10 & -0.1942 & 0.0646 \\
\hline 11 & -0.2111 & 0.1728 & 11 & -0.0724 & 0.0650 \\
\hline 12 & 0.1442 & 0.1731 & 12 & 0.0589 & 0.0649 \\
\hline 13 & 0.2681 & 0.1729 & 13 & 0.1352 & 0.0650 \\
\hline 14 & -0.0750 & 0.1733 & 14 & 0.0262 & 0.0654 \\
\hline 15 & -0.0217 & 0.1732 & 15 & -0.0415 & 0.0642 \\
\hline 16 & 0.1075 & 0.1732 & 16 & -0.0646 & 0.0632 \\
\hline 17 & -0.0547 & 0.1723 & 17 & -0.0795 & 0.0623 \\
\hline 18 & 0.0427 & 0.1720 & 18 & -0.1119 & 0.0618 \\
\hline 19 & -0.2182 & 0.1720 & 19 & -0.1480 & 0.0608 \\
\hline 20 & 0.2462 & 0.1722 & 20 & -0.1515 & 0.0593 \\
\hline 21 & 0.0040 & 0.1714 & 21 & -0.0615 & 0.0580 \\
\hline 22 & -0.3160 & 0.1709 & 22 & -0.0603 & 0.0548 \\
\hline 23 & 0.1384 & 0.1710 & 23 & -0.0765 & 0.0517 \\
\hline 24 & -0.0338 & 0.1709 & 24 & -0.0203 & 0.0426 \\
\hline \multicolumn{6}{|c|}{$R^{2}=0.61$} \\
\hline \multicolumn{6}{|c|}{ Specification 1: Panic Dummy $=\{$ Panics with 2 or 3 on Dimension 1$\}$} \\
\hline & \multicolumn{2}{|c|}{ Banking Panic } & \multicolumn{3}{|c|}{ Change in Index } \\
\hline Lag & \multicolumn{2}{|c|}{ Coefficient Standard Error } & Lag & Coefficient & rd Error \\
\hline 0 & -0.2177 & 0.1356 & \multicolumn{2}{|c|}{ 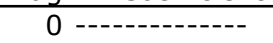 } & ----- \\
\hline 1 & -0.2783 & 0.1359 & 1 & -0.6693 & 0.0458 \\
\hline 2 & -0.6486 & 0.1363 & 2 & -0.4321 & 0.0544 \\
\hline 3 & -0.3393 & 0.1394 & 3 & -0.4551 & 0.0570 \\
\hline 4 & -0.3121 & 0.1400 & 4 & -0.3605 & 0.0601 \\
\hline 5 & -0.0778 & 0.1403 & 5 & -0.3406 & 0.0612 \\
\hline 6 & 0.0116 & 0.1402 & 6 & -0.2645 & 0.0623 \\
\hline 7 & -0.1746 & 0.1401 & 7 & -0.1611 & 0.0631 \\
\hline 8 & 0.1513 & 0.1402 & 8 & -0.1652 & 0.0630 \\
\hline 9 & 0.1484 & 0.1399 & 9 & -0.2096 & 0.0634 \\
\hline 10 & -0.2282 & 0.1400 & 10 & -0.1567 & 0.0641 \\
\hline 11 & -0.0628 & 0.1401 & 11 & -0.0318 & 0.0644 \\
\hline 12 & 0.2577 & 0.1402 & 12 & 0.0997 & 0.0640 \\
\hline 13 & 0.3450 & 0.1406 & 13 & 0.1758 & 0.0640 \\
\hline 14 & 0.0475 & 0.1414 & 14 & 0.0589 & 0.0646 \\
\hline 15 & 0.0286 & 0.1413 & 15 & -0.0142 & 0.0636 \\
\hline 16 & 0.1079 & 0.1412 & 16 & -0.0338 & 0.0628 \\
\hline 17 & -0.0356 & 0.1406 & 17 & -0.0666 & 0.0617 \\
\hline 18 & -0.0568 & 0.1405 & 18 & -0.1204 & 0.0612 \\
\hline 19 & -0.1868 & 0.1405 & 19 & -0.1635 & 0.0602 \\
\hline 20 & 0.0483 & 0.1406 & 20 & -0.1775 & 0.0587 \\
\hline 21 & -0.0129 & 0.1398 & 21 & -0.0873 & 0.0573 \\
\hline 22 & -0.2294 & 0.1394 & 22 & -0.0840 & 0.0542 \\
\hline 23 & 0.0845 & 0.1394 & 23 & -0.0901 & 0.0512 \\
\hline 24 & -0.1142 & 0.1390 & 24 & -0.0276 & 0.0422 \\
\hline$R^{2}=0.6$ & & & & & \\
\hline
\end{tabular}


Table 12. The Impact of Banking Panics on Prices

\begin{tabular}{|c|c|c|c|c|c|}
\hline & \multicolumn{4}{|c|}{ Specification 1: Panic Dummy $=\{$ Panics with 3 on Dimension 1$\}$} & Change in Prices \\
\hline Lag & \multicolumn{2}{|c|}{ Coefficient Standard Error } & Lag & \multicolumn{2}{|c|}{ Coefficient Standard Error } \\
\hline 0 & 0.0012 & 0.0121 & \multicolumn{3}{|c|}{0 - } \\
\hline 1 & -0.0172 & 0.0121 & 1 & 0.3007 & 0.0391 \\
\hline 2 & -0.0420 & 0.0121 & 2 & 0.0471 & 0.0407 \\
\hline 3 & -0.0123 & 0.0122 & 3 & -0.0039 & 0.0409 \\
\hline 4 & 0.0162 & 0.0122 & 4 & -0.0409 & 0.0408 \\
\hline 5 & -0.0173 & 0.0122 & 5 & -0.0289 & 0.0409 \\
\hline 6 & -0.0066 & 0.0123 & 6 & 0.0136 & 0.0409 \\
\hline 7 & 0.0015 & 0.0123 & 7 & -0.0731 & 0.0405 \\
\hline 8 & -0.0091 & 0.0122 & 8 & 0.1472 & 0.0405 \\
\hline 9 & -0.0102 & 0.0123 & 9 & -0.0313 & 0.0410 \\
\hline 10 & -0.0041 & 0.0123 & 10 & -0.0289 & 0.0412 \\
\hline 11 & 0.0005 & 0.0122 & 11 & -0.0209 & 0.0412 \\
\hline 12 & 0.0026 & 0.0122 & 12 & -0.0092 & 0.0412 \\
\hline \multicolumn{6}{|c|}{$\mathrm{R}^{2}=0.19$} \\
\hline \multicolumn{6}{|c|}{$\begin{array}{c}\text { Specification 2: Panic Dummy }= \\
\text { Banking Panic Shock }\end{array}$} \\
\hline Lag & Coefficient & d Error & Lag & \multicolumn{2}{|c|}{ Coefficient Standard Error } \\
\hline 0 & 0.0026 & 0.0105 & & - - & ------ \\
\hline 1 & -0.0242 & 0.0105 & 1 & 0.2971 & 0.0391 \\
\hline 2 & -0.0341 & 0.0105 & 2 & 0.0453 & 0.0407 \\
\hline 3 & -0.0114 & 0.0106 & 3 & 0.0009 & 0.0409 \\
\hline 4 & 0.0092 & 0.0106 & 4 & -0.0409 & 0.0408 \\
\hline 5 & -0.0109 & 0.0106 & 5 & -0.0301 & 0.0409 \\
\hline 6 & -0.0010 & 0.0106 & 6 & 0.0189 & 0.0409 \\
\hline 7 & 0.0018 & 0.0106 & 7 & -0.0686 & 0.0404 \\
\hline 8 & -0.0058 & 0.0106 & 8 & 0.1445 & 0.0404 \\
\hline 9 & -0.0051 & 0.0106 & 9 & -0.0322 & 0.0409 \\
\hline 10 & -0.0056 & 0.0106 & 10 & -0.0256 & 0.0411 \\
\hline 11 & -0.0001 & 0.0106 & 11 & -0.0183 & 0.0411 \\
\hline 12 & 0.0046 & 0.0106 & 12 & -0.0141 & 0.0411 \\
\hline \multicolumn{6}{|c|}{$\mathrm{R}^{2}=0.19$} \\
\hline \multicolumn{6}{|c|}{$\begin{array}{c}\text { Specification 3: Panic Dummy }= \\
\text { Banking Panic Shock }\end{array}$} \\
\hline Lag & Coefficient & d Error & Lag & \multicolumn{2}{|c|}{ Coefficient Standard Error } \\
\hline 0 & 0.0014 & 0.0148 & & - & ----- \\
\hline 1 & -0.0214 & 0.0148 & 1 & 0.3057 & 0.0390 \\
\hline 2 & -0.0483 & 0.0149 & 2 & 0.0433 & 0.0407 \\
\hline 3 & 0.0014 & 0.0150 & 3 & -0.0028 & 0.0409 \\
\hline 4 & -0.0005 & 0.0150 & 4 & -0.0337 & 0.0408 \\
\hline 5 & -0.0254 & 0.0149 & 5 & -0.0283 & 0.0408 \\
\hline 6 & 0.0066 & 0.0150 & 6 & 0.0090 & 0.0408 \\
\hline 7 & 0.0068 & 0.0150 & 7 & -0.0700 & 0.0404 \\
\hline 8 & -0.0018 & 0.0150 & 8 & 0.1485 & 0.0405 \\
\hline 9 & -0.0116 & 0.0150 & 9 & -0.0353 & 0.0409 \\
\hline 10 & 0.0052 & 0.0150 & 10 & -0.0263 & 0.0411 \\
\hline 11 & -0.0092 & 0.0149 & 11 & -0.0191 & 0.0412 \\
\hline 12 & 0.0049 & 0.0149 & 12 & -0.0147 & 0.0411 \\
\hline $\mathrm{R}^{2}=0.1$ & & & & & \\
\hline
\end{tabular}


Table 13.

\begin{tabular}{|cccr|}
\hline \multicolumn{5}{|c|}{ Turning Points in the Prewar U.S. } \\
Industrial Economy, 1830-1915 \\
\hline \hline $\begin{array}{c}\text { Peak } \\
\text { Antebellum Industrial Cycles }\end{array}$ & Major Panic & $\begin{array}{r}\text { \% Change in } \\
\text { Davis Index }\end{array}$ \\
\hline 1828 & 1829 & No Major Panic & -6.0 \\
$\mathbf{1 8 3 3}$ & $\mathbf{1 8 3 4}$ & Panic of 1833 & $-\mathbf{4 . 5}$ \\
$\mathbf{1 8 3 6}$ & $\mathbf{1 8 3 7}$ & Panic of 1837 & $\mathbf{- 1 . 4}$ \\
$\mathbf{1 8 3 9}$ & $\mathbf{1 8 4 0}$ & Panic of 1839 & $-\mathbf{4 . 7}$ \\
$\mathbf{1 8 5 6}$ & $\mathbf{1 8 5 8}$ & Panic of 1857 & $\mathbf{- 8 . 0}$ \\
Civil War Industrial Cycles & & \\
\hline 1860 & 1861 & No Major Panic & -0.9 \\
1864 & 1865 & No Major Panic & -5.2 \\
Postbellum Industrial Cycles & & $\mathbf{- 6 . 0}$ \\
\hline $\mathbf{1 8 7 3}$ & $\mathbf{1 8 7 5}$ & Panic of 1873 & -6.3 \\
1883 & 1885 & No Major Panic & $\mathbf{- 1 5 . 3}$ \\
$\mathbf{1 8 9 2}$ & $\mathbf{1 8 9 4}$ & Panic of 1893 & -3.1 \\
1895 & 1896 & No Major Panic & -4.7 \\
1903 & 1904 & No Major Panic & $\mathbf{- 1 5 . 6}$ \\
$\mathbf{1 9 0 7}$ & $\mathbf{1 9 0 8}$ & Panic of 1907 \\
1910 & 1911 & No Major Panic & -3.7 \\
1913 & 1914 & No Major Panic & -10.2 \\
\hline
\end{tabular}


Table 14. Downturns with Major Banking Panics vs Downturns without Major Banking Panics

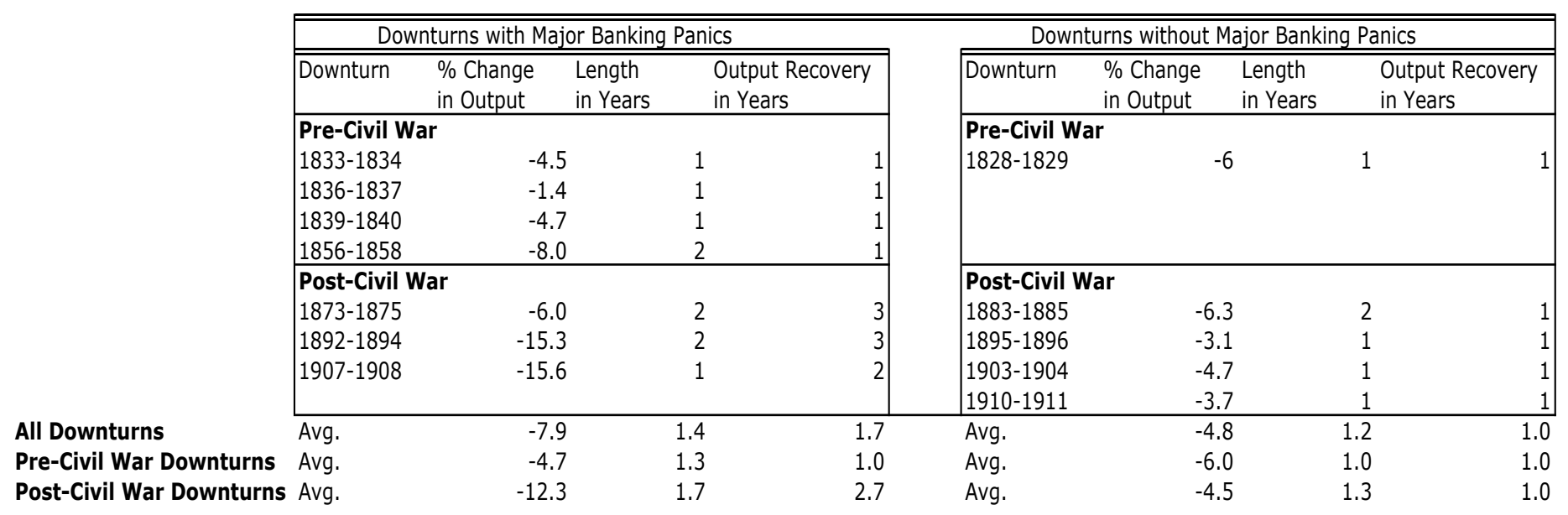


Table 15. Breaks in Trend

$\ln y_{t}=\alpha_{0}+\alpha_{1} D_{t}+\beta_{0} t+\beta_{1} D_{t} t+\varepsilon_{t}$

\begin{tabular}{|c|c|c|}
\hline & Coefficient & Standard Error \\
\hline \multicolumn{3}{|c|}{ Panic of 1857} \\
\hline$\alpha_{0}$ & 5.2117 & 0.0537 \\
\hline$\beta_{0}$ & 0.0753 & 0.0059 \\
\hline$\alpha_{1}$ & -0.2605 & 0.0573 \\
\hline $\begin{array}{c}\beta_{1} \\
\text { Panic of } \mathbf{1 8 7 3}\end{array}$ & -0.0284 & 0.0063 \\
\hline$\alpha_{0}$ & 5.6964 & 0.0209 \\
\hline$\beta_{0}$ & 0.0461 & 0.0024 \\
\hline$\alpha_{1}$ & -0.0963 & 0.0412 \\
\hline $\begin{array}{c}\beta_{1} \\
\text { Panic of } 1893\end{array}$ & 0.0173 & 0.0036 \\
\hline$\alpha_{0}$ & 6.8044 & 0.0240 \\
\hline$\beta_{0}$ & 0.0630 & 0.0041 \\
\hline$\alpha_{1}$ & -0.2093 & 0.0393 \\
\hline $\begin{array}{c}\beta_{1} \\
\text { Panic of } \mathbf{1 9 0 7}\end{array}$ & 0.0002 & 0.0053 \\
\hline$\alpha_{0}$ & 7.5424 & 0.0259 \\
\hline$\beta_{0}$ & 0.0632 & 0.0034 \\
\hline$\alpha_{1}$ & -0.1740 & 0.0545 \\
\hline$\beta_{1}$ & -0.0309 & 0.0114 \\
\hline
\end{tabular}


Figure 1. Classification Algorithm

Dimension 1

Reported Causes

1

Primary Cause: Event Related
to Output Fluctuations
--Downturn

$\left.\right|^{2}$

Mixed Causes: Records

Cite a Downturn as well an Event Unrelated to Output

Fluctuations (political decisions, failure mismanaged bank, intl. contagion)
Primary Cause: Event Unrelated to Output Fluctuations --Political Decision --Failure of Mismanaged Bank --International Contagion

Dimension 2

State of the Economy

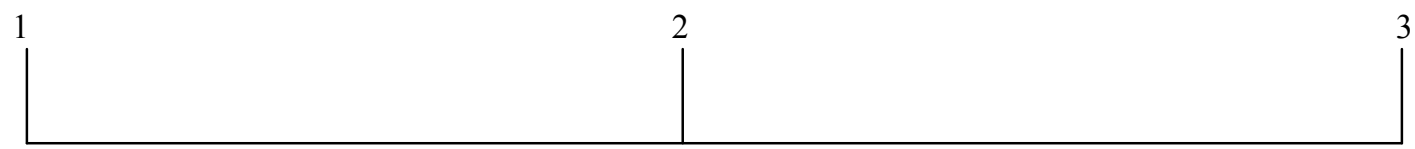

Depression/Recession on the Eve of the Outbreak of Panic
Mixed Reporting: Records do not clearly characterize conditions as either "prosperous" or as in "depression/recession"
Prosperity on the Eve of the Outbreak of Panic 
Figure 2. The Impact of a Major Banking Panic on Industrial Production

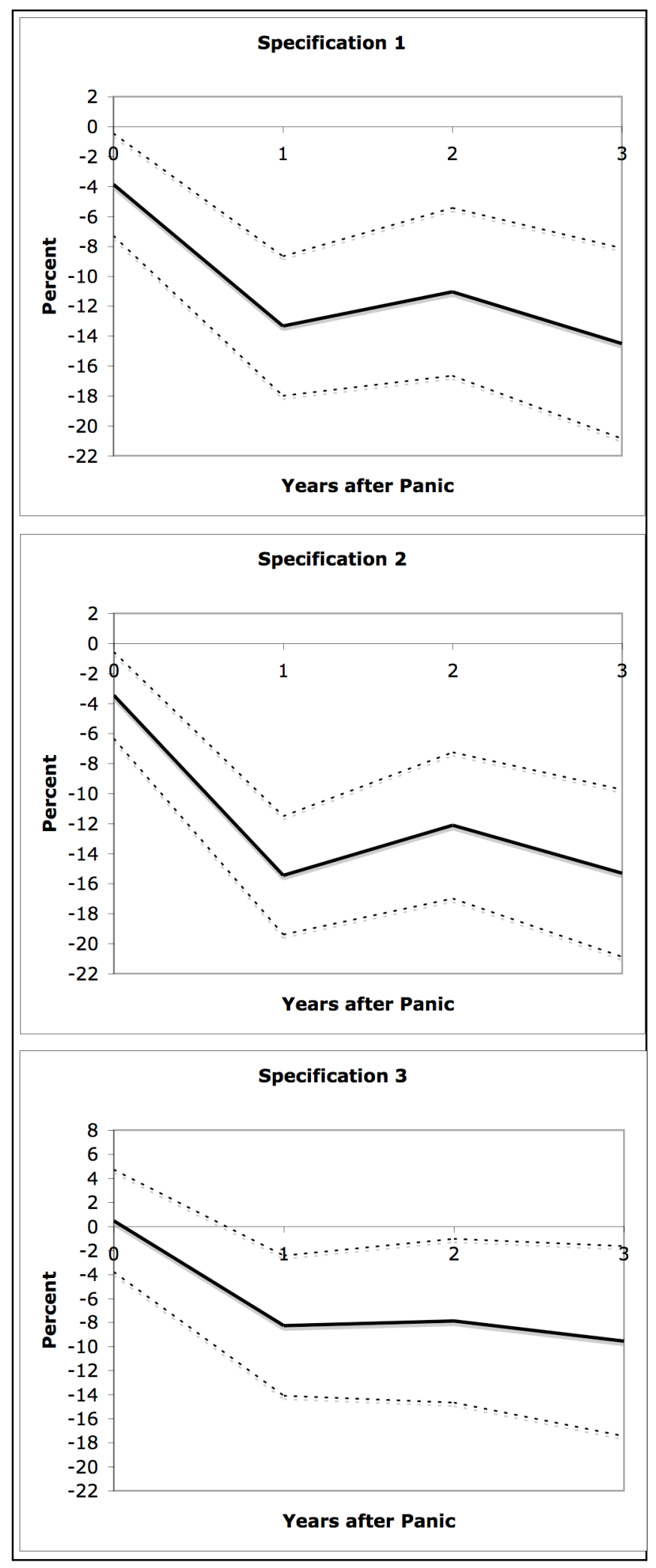


Figure 3. The Impact of a Major Banking Panic on Construction

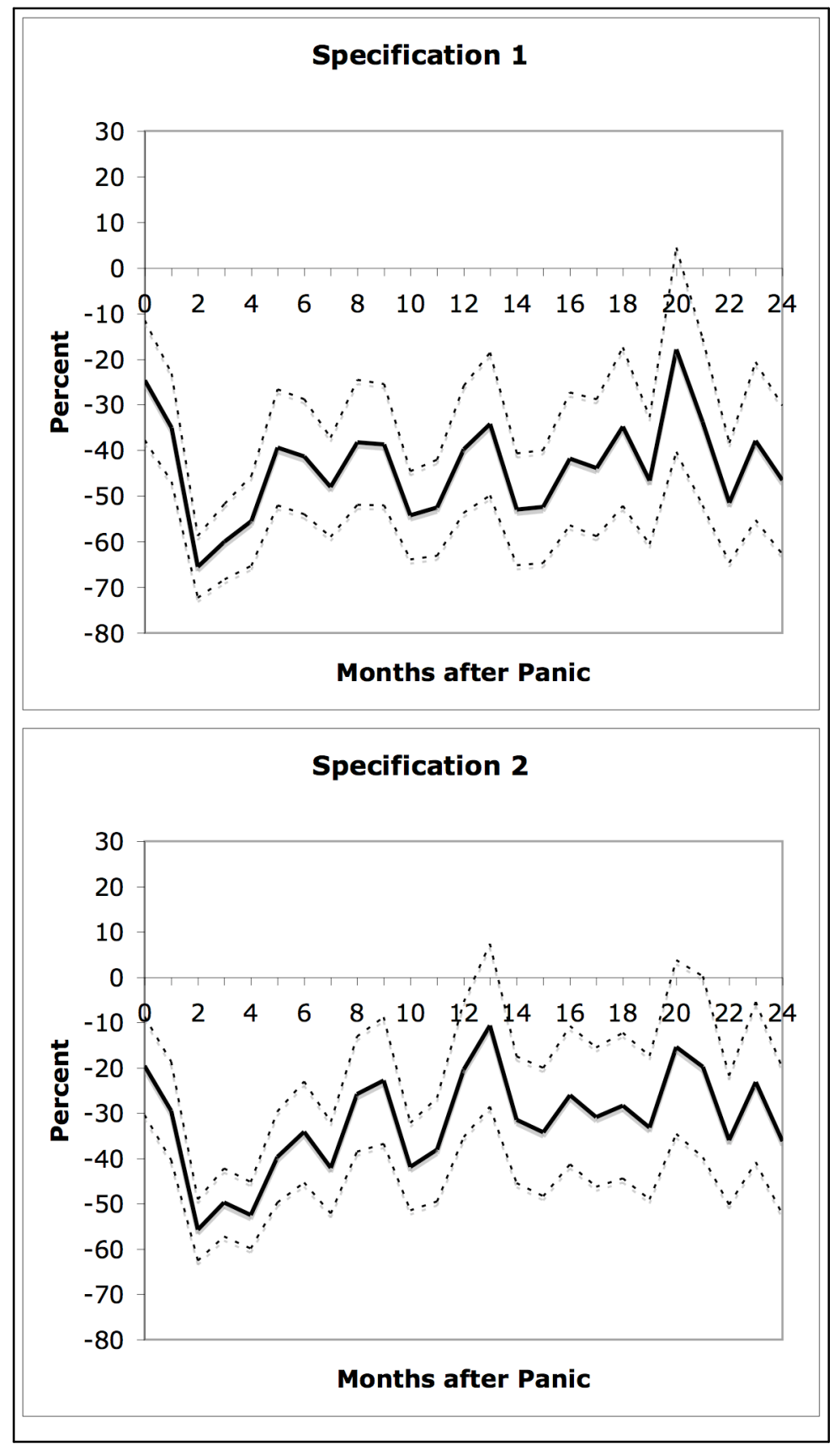


Figure 4. The Impact of a Major Banking Panic on the Price Level

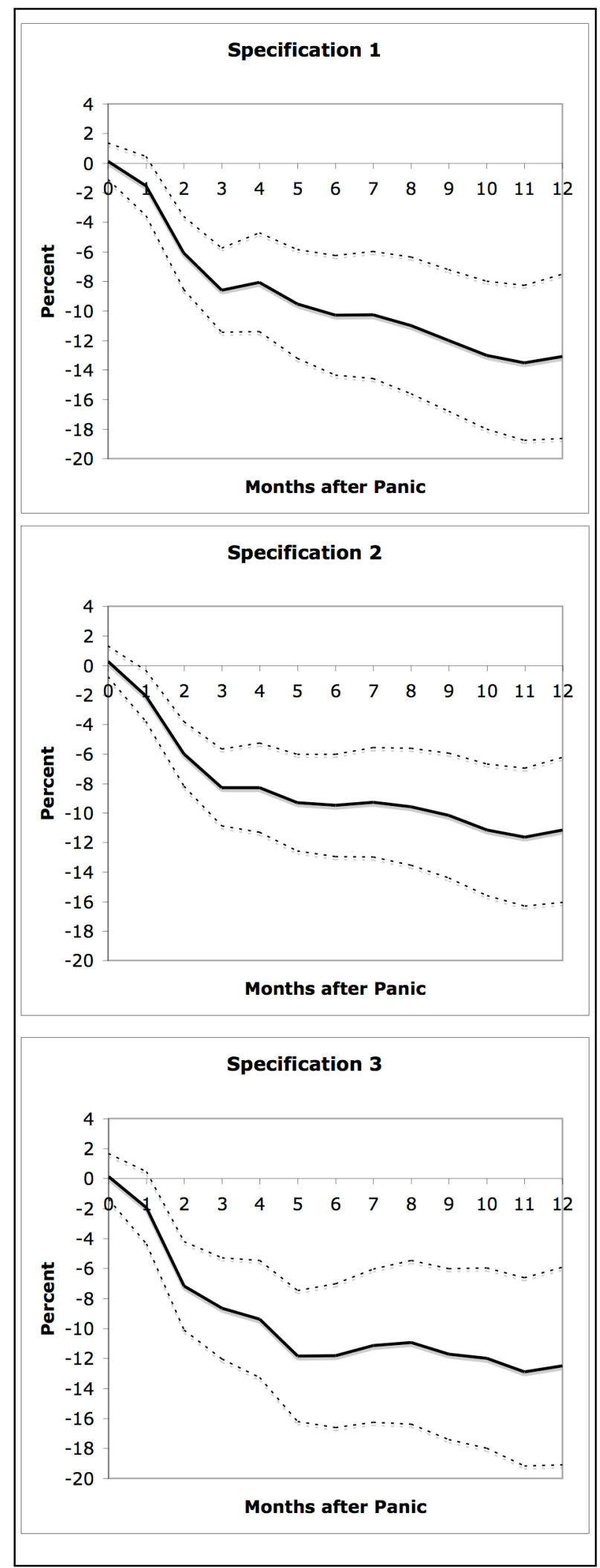


Figure 5. Breaks in Level and Trend at Beginning of Post-Panic Period
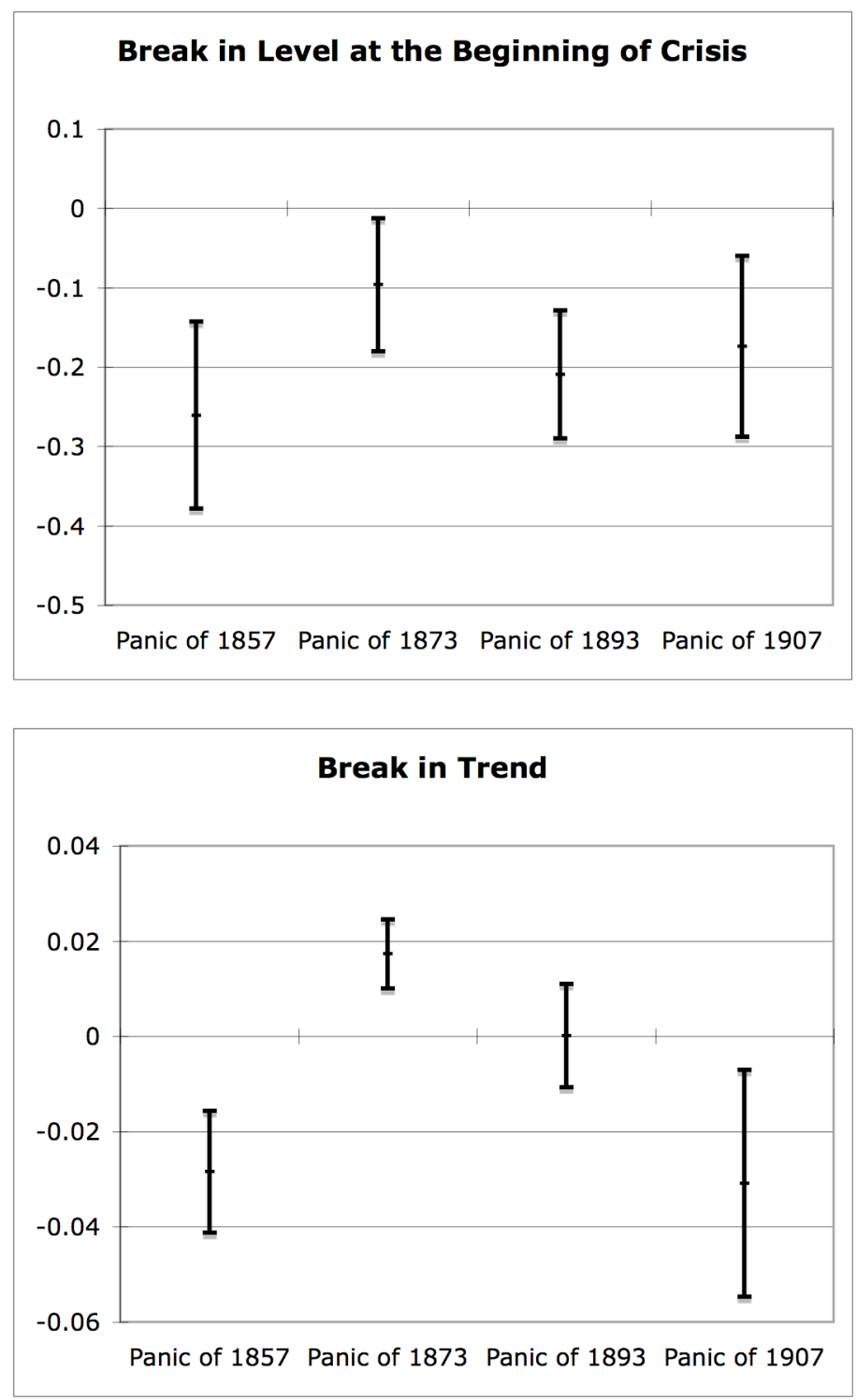
Figure 6. Actual and Projected Trend Lines (Panics of 1857, 1873, 1893, and 1907)
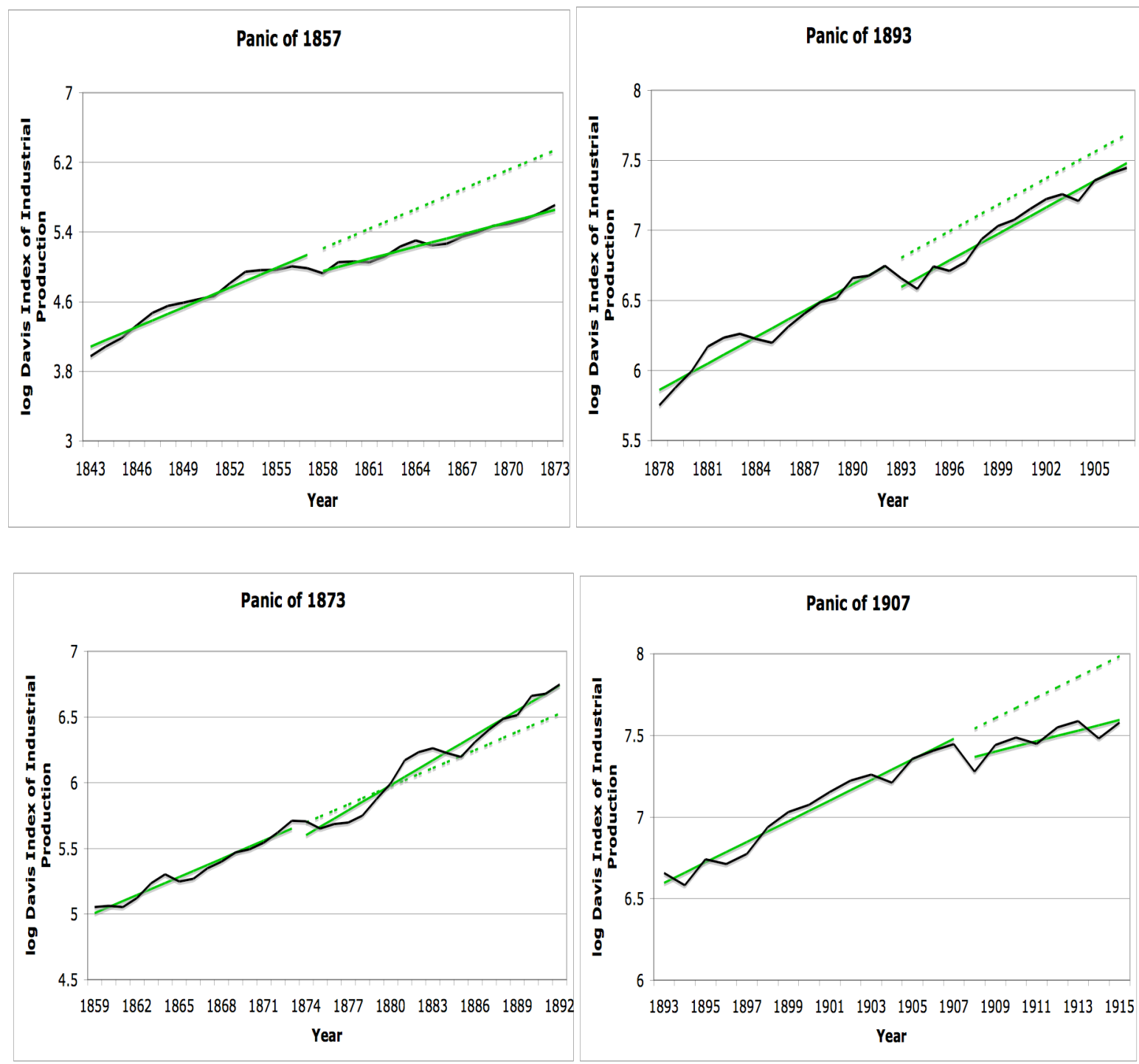